\title{
Histology-free Descriptions for Seven Species of Interstitial Ribbon Worms in the Genus Ototyphlonemertes (Nemertea: Monostilifera) from Vietnam
}

\author{
Hiroshi Kajihara ${ }^{1,4}$, Kotaro Tamura ${ }^{2}$, and Shinri Tomioka ${ }^{3}$ \\ ${ }^{1}$ Faculty of Science, Hokkaido University, N10 W8, Sapporo, Hokkaido 060-0810, Japan \\ E-mail: kajihara@eis.hokudai.ac.jp \\ ${ }^{2}$ Zukosha, W18 N1, Obihiro, Hokkaido 080-0048, Japan \\ ${ }^{3}$ Rishiri Town Museum, Senhoshi, Rishiri Is., Hokkaido 097-0311, Japan \\ ${ }^{4}$ Corresponding author
}

(Received 20 September 2017; Accepted 4 December 2017)

http://zoobank.org/870A4A76-9855-46CE-A0A5-7E7870F4E548

\begin{abstract}
Seven (including six new) species of interstitial hoplonemerteans in the genus Ototyphlonemertes Diesing, 1863 are described from southern Vietnam. The descriptions are based on light microscopic examination of internal structures as well as three methods of molecular species delimitation analyses, i) Automatic Barcode Gap Discovery (ABGD), ii) Poisson Tree Process (PTP), and iii) statistical parsimony, on the basis of $\sim 658$-bp cytochrome $c$ oxidase subunit I gene sequences that have been $i$ ) newly determined from the Vietnamese specimens and ii) deposited in the public databases for other Ototyphlonemertes species. Three taxa are circumscribed as 'species groups' and placed at an infra-subgeneric, supra-specific rank, each represented by O. duplex Bürger, 1895, O. macintoshi Bürger, 1895, and O. parmula Corrêa, 1950. Of the seven Vietnamese species, one is identified as Ototyphlonemertes (species group macintoshi) ani Chernyshev, 2007, which is molecularly confirmed to be distributed from Vietnam (Phu Quoc and Nha Trang) to Japan (Okinawa and Wakayama). The other six are new to science, to which formal taxonomic descriptions are given: these are $O$. (duplex) chernyshevi sp. nov., O. (duplex) envalli sp. nov., O. (duplex) norenburgi sp. nov., O. (parmula) lei sp. nov., O. (parmula) nakaoae sp. nov., and $O$. (parmula) tsukagoshii sp. nov.
\end{abstract}

Key Words: COI, DNA taxonomy, Gulf of Thailand, Hoplonemertea, marine invertebrates, meiobenthos, TCS.

\section{Introduction}

Ribbon worms in the genus Ototyphlonemertes Diesing, 1863 are exclusively mesopsammic, living in interstices of coarse sand grains in intertidal and shallow subtidal zones almost all over the world except the Antarctica (Kirsteuer 1977; Norenburg 1988a; Leasi et al. 2016). They have morphological features that are likely to be the results of adaptation to the interstitial environment; these include slender body $(\sim 500 \mu \mathrm{m})$, statocysts in the cerebral ganglia, welldeveloped tactile or sensory cirri both on the head and tail, lack of eyes, and caudal adhesion plate (Norenburg 1988a). Currently recognized 27 named species (Norenburg and Gibson 2012), as well as $\sim 100$ unnamed morphospecies, can be categorized into several groups (Envall and Norenburg 2001), but reliable species discrimination cannot be achieved without DNA-sequence information in many cases (Leasi and Norenburg 2014; Leasi et al. 2016). However, none of the molecularly-discovered unnamed taxa have been formally described as new species in the Ototyphlonemertes systematics so far.

Vietnamese nemerteans have been investigated by Joubin (1905), Dawydoff (1940, 1952), and Chernyshev (2007, 2011, 2016), with about 24 named and 58 undetermined species reported so far. Of these, Ototyphlonemertes ani Chernyshev, 2007 and O. cf. martynovi Chernyshev, 1993 are mesopsammic, meiobenthic representatives, while others are mostly macrobenthic, implying a biased sampling efforts in previous studies towards macrobenthos-sized species, with less attention to interstitial ones.

In this paper, we describe seven (including six new) species of Ototyphlonemertes from two, small, uninhabited islands in southern Vietnam, based on morphological characters examined in vivo, in combination with an approach of so-called DNA taxonomy (e.g., Fontaneto et al. 2015). Although some of the previous taxonomic descriptions of Ototyphlonemertes species involved histological sectioning (e.g., Chernyshev 2007; Kajihara 2007) like in many other groups of nemerteans (Gibson 1985), we establish new species without histology in this paper ( $c f$. Strand and Sundberg 2011; Kajihara 2015).

\section{Materials and Methods}

\section{Sampling and morphological observation}

Sandy sediment samples were collected at two small beaches, each on the islands of Dam Trong $\left(9^{\circ} 59^{\prime} 58.402^{\prime \prime} \mathrm{N}\right.$, $\left.104^{\circ} 02^{\prime} 5.914^{\prime \prime} \mathrm{E}\right)$ and Dam Ngoai $\left(9^{\circ} 59^{\prime} 42.533^{\prime \prime} \mathrm{N}\right.$, 
$\left.104^{\circ} 02^{\prime} 16.537^{\prime \prime} \mathrm{E}\right)$, on 21 November 2014 . The two beaches are about $400 \mathrm{~m}$ apart, situated to the south of Phu Quoc, southern Vietnam, facing on the Gulf of Thailand (Fig. 1). Ribbon worms were extracted from the sand following the

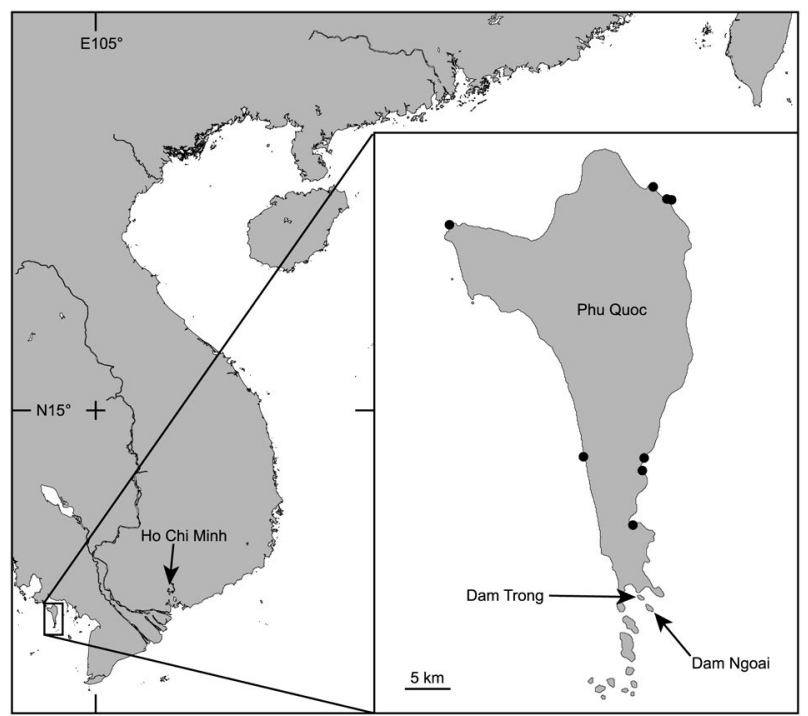

Fig. 1. Map showing the two sampling localities, the islands of Dam Trong and Dam Ngoai, situated to the south of the southern tip of Phu Quoc, Vietnam. Solid circles around the main island of Phu Quoc indicate the localities where interstitial nemerteans were sought but not found. method of Corrêa (1953): the sand is placed half in a plastic tray $(30 \times 25 \times 6 \mathrm{~cm})$, which is then slightly tilted on the beach, with the sand-filled side upward; as sea water is gently sprinkled over the sand using a polyethylene wash bottle, the worms slide down along with the sea water to the non-filled side of the tray, due to their positive geotaxis. The worms were anaesthetized in $\mathrm{MgCl}_{2}$ solution prepared with tap water so that it had the same refractive index (or 'salinity') as that of the sea water using an IS/Mill-E fractometer (AS ONE, Japan). Of the 31 specimens collected (10 from Dam Trong, 21 from Dam Ngoai), 14 were photographed alive with a RICOH CX 5 digital camera, then mounted on a glass slide under a cover slip (Kirsteuer 1967), observed with an Olympus $\mathrm{CH}-2$ compound microscope (Olympus, Japan); photomicrographs of squeezed, live specimens were taken with a Nikon D5200 digital camera attached to the CH-2 microscope by Micronet NYPIXS2-3166, HY 1S-FA, and NY 1S-1501750 adapters. The rest of the 17 specimens were also photographed alive with a Nikon D5200 digital camera attached to a Nikon SMZ 1500 stereomicroscope by the same adapters, with external strobe lighting provided by a pair of Morris Hikaru Komachi Di flash units; the specimens were likewise squeezed then examined under an Olympus BX51 compound microscope, and also photographed with the same Nikon D5200 digital camera. After examination, all the worms were preserved in $99 \% \mathrm{EtOH}$. Type and voucher specimens in the form of extracted DNA have been deposited in the Invertebrate Collection of the

Table 1. Museum catalogue number (ICHUM), type status, locality, and DDBJ/EMBL/GenBank accession number for COI sequences determined from 25 specimens in seven species of Ototyphlonemertes from Vietnam.

\begin{tabular}{|c|c|c|c|c|}
\hline ICHUM & Type status & Species & Locality & $\begin{array}{c}\text { Accession } \\
\text { number }\end{array}$ \\
\hline 5348 & holotype & Ototyphlonemertes (duplex) chernyshevi sp. nov. & Dam Trong & LC310990 \\
\hline 5349 & paratype & Ototyphlonemertes (duplex) chernyshevi sp. nov. & Dam Trong & LC310991 \\
\hline 5350 & paratype & Ototyphlonemertes (duplex) chernyshevi sp. nov. & Dam Trong & LC310992 \\
\hline 5351 & holotype & Ototyphlonemertes (duplex) envalli sp. nov. & Dam Trong & LC310993 \\
\hline 5352 & paratype & Ototyphlonemertes (duplex) envalli sp. nov. & Dam Trong & LC310994 \\
\hline 5353 & paratype & Ototyphlonemertes (duplex) envalli sp. nov. & Dam Trong & LC310995 \\
\hline 5354 & paratype & Ototyphlonemertes (duplex) envalli sp. nov. & Dam Trong & LC310996 \\
\hline 5355 & holotype & Ototyphlonemertes (duplex) norenburgi sp. nov. & Dam Ngoai & LC310997 \\
\hline 5356 & paratype & Ototyphlonemertes (duplex) norenburgi sp. nov. & Dam Ngoai & LC310998 \\
\hline 5357 & non-type & Ototyphlonemertes (macintoshi) ani Chernyshev, 2007 & Dam Ngoai & LC310999 \\
\hline 5358 & non-type & Ototyphlonemertes (macintoshi) ani Chernyshev, 2007 & Dam Ngoai & LC311000 \\
\hline 5359 & non-type & Ototyphlonemertes (macintoshi) ani Chernyshev, 2007 & Dam Ngoai & LC311001 \\
\hline 5360 & non-type & Ototyphlonemertes (macintoshi) ani Chernyshev, 2007 & Dam Ngoai & LC311002 \\
\hline 5361 & non-type & Ototyphlonemertes (macintoshi) ani Chernyshev, 2007 & Dam Ngoai & LC311003 \\
\hline 5362 & non-type & Ototyphlonemertes (macintoshi) ani Chernyshev, 2007 & Dam Ngoai & LC311004 \\
\hline 5363 & non-type & Ototyphlonemertes (macintoshi) ani Chernyshev, 2007 & Dam Ngoai & LC311005 \\
\hline 5364 & non-type & Ototyphlonemertes (macintoshi) ani Chernyshev, 2007 & Dam Ngoai & LC311006 \\
\hline 5365 & holotype & Ototyphlonemertes (parmula) lei sp. nov. & Dam Ngoai & LC311007 \\
\hline 5366 & holotype & Ototyphlonemertes (parmula) nakaoae sp. nov. & Dam Trong & LC311008 \\
\hline 5367 & paratype & Ototyphlonemertes (parmula) nakaoae sp. nov. & Dam Trong & LC311009 \\
\hline 5368 & paratype & Ototyphlonemertes (parmula) nakaoae sp. nov. & Dam Ngoai & LC311010 \\
\hline 5369 & paratype & Ototyphlonemertes (parmula) nakaoae sp. nov. & Dam Ngoai & LC311011 \\
\hline 5370 & paratype & Ototyphlonemertes (parmula) nakaoae sp. nov. & Dam Ngoai & LC311012 \\
\hline 5371 & holotype & Ototyphlonemertes (parmula) tsukagoshii sp. nov. & Dam Ngoai & LC311013 \\
\hline 5372 & paratype & Ototyphlonemertes (parmula) tsukagoshii sp. nov. & Dam Ngoai & LC311014 \\
\hline
\end{tabular}


Hokkaido University Museum (ICHUM), Sapporo, Japan.

No interstitial nemerteans were found at eight sites around the main island of Phu Quoc (Fig. 1) on 20 November 2014. These sites were: a beach along the western coast of the island in Duong Bao $\left(10^{\circ} 08^{\prime} 33.1^{\prime \prime} \mathrm{N}, 103^{\circ} 58^{\prime} 30.1^{\prime \prime} \mathrm{E}\right)$, a small bay on the eastern coast of the island in Duong Bao north to the border between An Thoi $\left(10^{\circ} 04^{\prime} 36.0^{\prime \prime} \mathrm{N}\right.$, $\left.104^{\circ} 01^{\prime} 18.1^{\prime \prime} \mathrm{E}\right)$, two places on the eastern coast of the island near Bai Vong $\left(10^{\circ} 08^{\prime} 44.9^{\prime \prime} \mathrm{N}, 104^{\circ} 02^{\prime} 05.3^{\prime \prime} \mathrm{E} ; 10^{\circ} 07^{\prime} 59.8^{\prime \prime} \mathrm{N}\right.$, $104^{\circ} 01^{\prime} 50.0^{\prime \prime} \mathrm{E}$ ), a small beach on the northeastern side of the island near Bai Thom $\left(10^{\circ} 24^{\prime} 51.7^{\prime \prime} \mathrm{N}, 104^{\circ} 02^{\prime} 31.7^{\prime \prime} \mathrm{E}\right)$, two places on the northeastern side of the island near Hom Mot $\left(10^{\circ} 24^{\prime} 08.8^{\prime \prime} \mathrm{N}, 104^{\circ} 03^{\prime} 26.4^{\prime \prime} \mathrm{E} ; 10^{\circ} 24^{\prime} 11.5^{\prime \prime} \mathrm{N}\right.$, $104^{\circ} 03^{\prime} 28.2^{\prime \prime} \mathrm{E}$ ), and a beach on the northwestern edge of the island near Bai bien Ganh Dau $\left(10^{\circ} 22^{\prime} 23.3^{\prime \prime} \mathrm{N}\right.$, $\left.103^{\circ} 50^{\prime} 18.1^{\prime \prime} \mathrm{E}\right)$.

\section{DNA extraction, PCR amplification, and sequencing}

Total DNA was extracted from the whole body using the silica method (Boom et al. 1990). PCR amplification was carried out for partial sequence of the cytochrome $c$ oxidase subunit I (COI) gene by using LCO1490/HCO2190 primer pair (Folmer et al. 1994) with an Applied Biosystems 2720 Thermal Cycler. The reaction was done in a $10-\mu$ l volume, containing 1-6ng of extracted total DNA, 2 nmol of each dNTP, 5 pmol of each primer, and $0.25 \mathrm{U}$ of Ex Taq (TaKaRa, Japan) in $1 \times$ Ex Taq Buffer (TaKaRa, Japan). Thermal cycling was initiated with $1 \mathrm{~min}$ of denaturation at $95^{\circ} \mathrm{C}$, followed by 35 cycles of $30 \mathrm{sec}$ at $95^{\circ} \mathrm{C}, 30 \mathrm{sec}$ at $50^{\circ} \mathrm{C}$, and $1 \mathrm{~min}$ at $72^{\circ} \mathrm{C}$. After cycling, the reaction was completed with a final extension at $72^{\circ} \mathrm{C}$ for $7 \mathrm{~min}$. The reaction products were visualized in a $1 \%$ agarose gel, then purified with about $5.7 \mathrm{mU} / \mu \mathrm{l}$ of shrimp alkaline phosphatase $(1 \mathrm{U} /$ $\mu \mathrm{l}$; TaKaRa, Japan) and $28.3 \mathrm{mU} / \mu \mathrm{l}$ of $E$. coli exonuclease I $(5 \mathrm{U} / \mu \mathrm{l}$; TaKaRa, Japan) in an $18-\mu \mathrm{l}$ volume for $30 \mathrm{~min}$ at $37^{\circ} \mathrm{C}$, followed by deactivation of the enzymes for $15 \mathrm{~min}$ at $80^{\circ} \mathrm{C}$. The purified PCR products were sequenced directly with the same primer pairs used for amplification, using a BigDye Terminator ver. 3.1 Sequencing Kit (Applied Biosystems, USA) and an ABI Prism 3730 Genetic Analyzer (Applied Biosystems, USA), following the manufacturer's protocol. For eight of the 33 specimens, either PCR amplification or DNA sequencing were unsuccessful. A total of 25 sequences generated de novo have been deposited in the DNA Data Bank of Japan (DDBJ) under accession numbers of LC310990-LC311014 (Table 1).

\section{Species delimitation analyses}

Three different methods were used for species delimitation analyses: Automatic Barcode Gap Discovery (ABGD) (Puillandre et al. 2012), Poisson Tree Processes (PTP) (Zhang et al. 2013), and statistical parsimony (Templeton et al. 1992). The analyses were based on the 25 newly determined COI sequences together with 462 others available in GenBank: HQ848613, HQ848605 (Andrade et al. 2012); KF935545 (Kvist et al. 2014); KM083821-083889, KM094175 (Leasi and Norenburg 2014); and KT3630336314, KT722707-722370, KT730596-730678, KU230031-
230291, KU245363-245364, KU840015, KU840020-840025 (Leasi et al. 2016) (see Appendix). Alignment was manually inspected using MEGA ver. 6.06 (Tamura et al. 2013) so that the sequences could be translated to amino acids. The ABGD analysis was carried out with the aligned sequence data set and performed in a web-based interface (http:// wwwabi.snv.jussieu.fr/public/abdg/abdgweb.html) with the following settings: Pmin, 0.001; Pmax, 0.1; Steps, 10; X (relative gap width), 1.5; Nb bins (for distance distribution), 20; distance, Kimura (K80) TS/TV 2.0. The PTP analysis was performed at the bPTP web server (http://species.h-its. org/ptp/) with the default settings using an input tree generated by RAxML ver. 8 (Stamatakis 2014) based on maximum-likelihood method with GTR $+\mathrm{G}+\mathrm{I}$ model. The statistical parsimony analysis was done with TCS ver. 1.21 (Clement et al. 2000). The following sequences were excluded from the analysis due to the shortness compared with the others: KM083830 (291 bp), KM083826 (452 bp), KM083825 (543bp), KU230098 (432 bp), KM083874 (432 bp), KM083865 (241 bp), and KM083863 (504bp). The TCS analysis was performed with 480 sequences ( $478 \mathrm{bp}$ ) [KM083825 and KM083863 are longer than this, but they have long uncertain positions at either end in relation to the aligned sites].

\section{Infra-generic taxonomy and nomenclature}

The taxonomy and nomenclature at the infra-generic, supra-specific ranks in Ototyphlonemertes have been in flux. Chernyshev (1993) proposed to segregate Ototyphlonemertes species with polygranular statoliths and transfer to a new genus Norenburgia Chernyshev, 1993 (type species: Ototyphlonemertes lactea Corrêa, 1954). Chernyshev (1993) also established Accirinia as a subgenus of Norenburgia, but it has not received general acceptance among researchers (e.g., Gibson 1995). Envall (1996) proposed Otohelicophora as a subgenus for members with spiral stylets, but this name is unavailable due to the lack of type fixation in the original publication (Chernyshev 1998; Kajihara et al. 2008). Chernyshev (1998) recognized two subgenera Ototyphlonemertes and Norenburgia, the former consisting of species with oligogranular statoliths and smooth central stylet, the latter with polygranular statoliths and smooth or sculptured central stylet. Subsequently, based on a combination of five characters (statolith, stylet, basis, diaphragm, and middle chamber), Envall and Norenburg (2001) put together all the $\sim 22$ named and $>70$ unidentified species known at the time into six groups that are represented by the first established species within each group, i.e., Ototyphlonemertes cirrula Mock and Schmidt, 1975, O. duplex Bürger, 1895, O. fila Corrêa, 1953 (but see below), O. lactea Corrêa, 1954, O. macintoshi Bürger, 1895, and O. pallida (Keferstein, 1862). These groups were variably referred to as phylogroup or morphotype, with the name of the groups indicated in nonitalic face beginning with an upper-case initial letter, such as "Duplex-type" (Envall and Norenburg 2001). In a molecular phylogeographic analysis of Ototyphlonemertes based on four gene markers (COI, 16S rRNA, 18S rRNA, 28S rRNA), Leasi et al. (2016) basically followed Envall and Noren- 


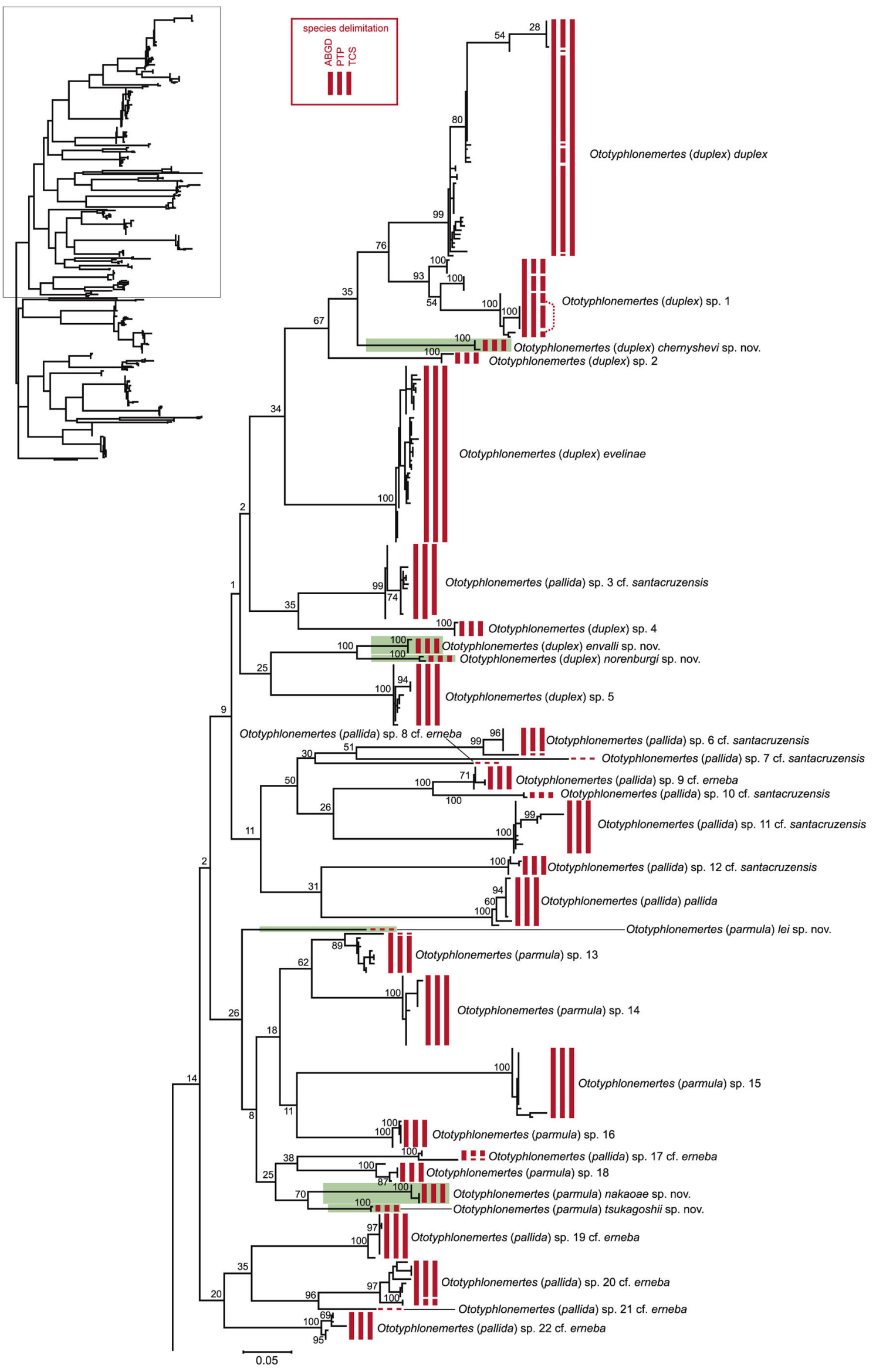

Fig. 2. Part of the phylogenetic tree resulting from the maximum-likelihood analysis of COI $(\ln L=-15264.650301)$, along with results of three species-delimitation analyses, ABGD, PTP, and TCS, as indicated by vertical bars. Numbers near nodes indicate maximum-likelihood bootstrap support value. 


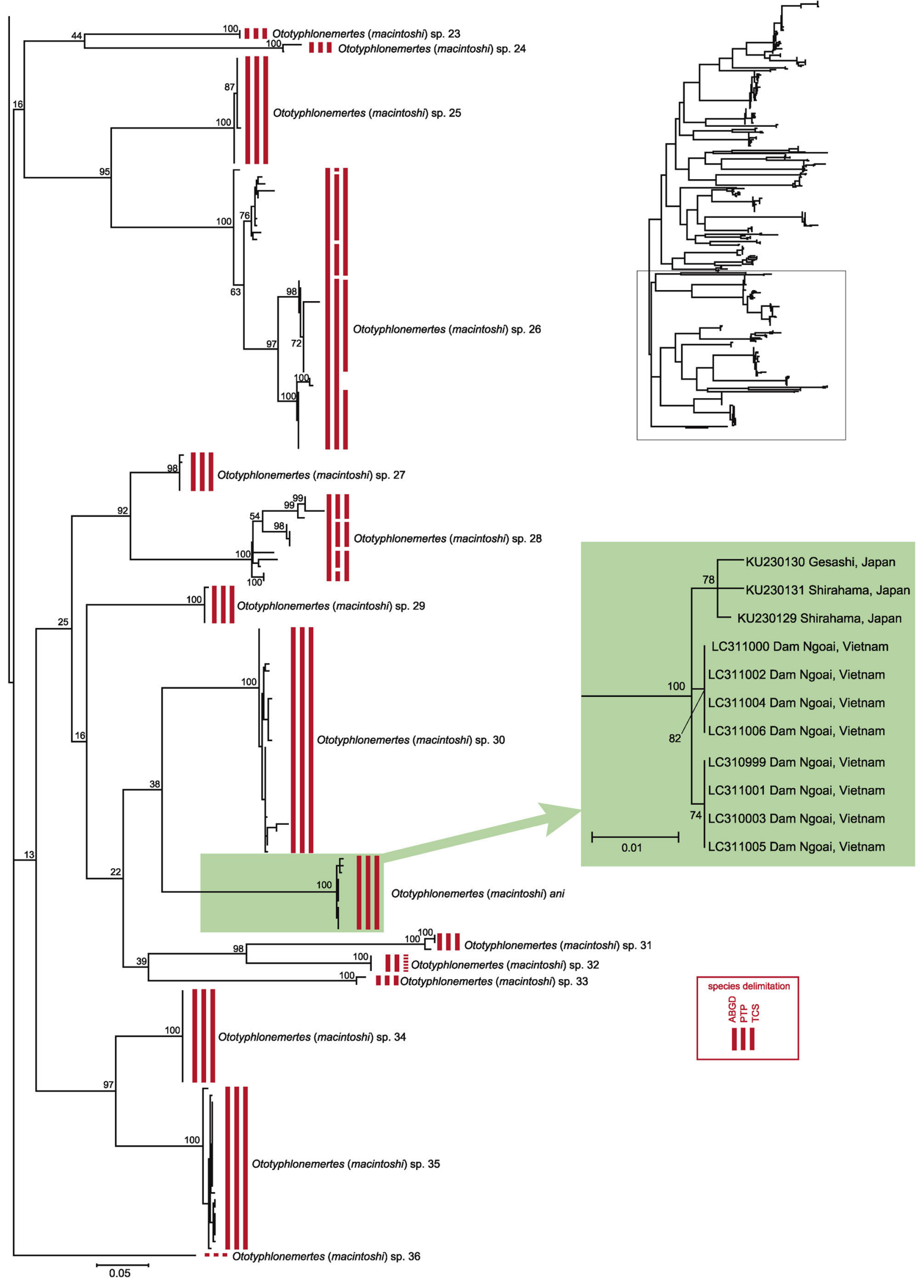

Fig. 3. Part of the phylogenetic tree resulting from the maximum-likelihood analysis of COI $(\ln L=-15264.650301)$, along with results of three species-delimitation analyses, ABGD, PTP, and TCS, as indicated by vertical bars. Numbers near nodes indicate maximum-likelihood bootstrap support value. 
burg's (2001) nomenclature, introducing new morphological groups Erneba and Santacruzensis, although these groups were not explicitly circumscribed with morphological characteristics.

To refer to these groups of species, we invoke Article 6.2 of the Code (International Commission on Zoological Nomenclature [ICZN] 1999), which stipulates "A specific name may be added in parentheses after the genus-group name..., to denote an aggregate of species within a genus-group taxon; ...such names...must always begin with a lower-case letter and be written in full" (ICZN 1999). These infra-subgeneric, supra-specific ranks are commonly referred to as 'superspecies', 'species aggregate', or 'species group'; we adopt the last one in this paper. Recommendation $6 \mathrm{~B}$ of the Code (ICZN 1999) states that this term (i.e., 'species group' in this case) should be placed to indicate the taxonomic meaning in the same parentheses as its interpolated species-group name on the first occasion (see below).

Ototyphlonemertes duplex species group. The Duplexmorph of Envall and Norenburg (2001) was corroborated by Leasi et al.'s (2016) molecular phylogeny as comprising a clade. This group can be diagnosed as having two-granular statoliths, smooth central stylet, thick central-stylet basis, short proboscis diaphragm, and bulbous proboscis middle chamber. It includes the recognized species $O$. (species group duplex) antipai Müller, 1968; O. (duplex) aurantiaca (Du Plessis, 1891); O. (duplex) brunnea Bürger, 1895; O. (duplex) correae Envall, 1996; O. (duplex) duplex Bürger, 1895; O. (duplex) evelinae Corrêa, 1948; and O. (duplex) martynovi Chernyshev, 1993.

Ototyphlonemertes macintoshi species group. Leasi et al.'s (2016) molecular phylogeny showed that the Macintoshi and Lactea morpho-groups of Envall and Norenburg (2001) together comprised a clade, but were not reciprocally monophyletic. In this paper, we regard these groups as synonymous and refer to it as the Ototyphlonemertes macintosh $i$ species group. It is because Article 6.2 of the Code (ICZN 1999) provides that the Principle of Priority applies to the names of such aggregate of species; $O$. macintosh $i$ was established by Bürger (1895), while O. lactea was by Corrêa (1954). The O. macintoshi species group can be diagnosed as having polygranular statoliths, spirally-sculptured central stylet, long proboscis diaphragm, and short or long proboscis middle chamber. It includes the recognized species $O$. (macintoshi) americana Gerner, 1969; O. (macintoshi) ani Chernyshev, 2007; O. (macintoshi) dolichobasis Kajihara, 2007; O. (macintoshi) lactea Corrêa, 1953; O. (macintoshi) macintoshi Bürger, 1895; O. (macintoshi) nikolaii Chernyshev, 1998; O. (macintoshi) pellucida Coe, 1943; O. (macintoshi) spiralis Coe, 1940; and O. (macintoshi) valentinae Chernyshev, 2003.

Ototyphlonemertes parmula species group. Envall and Norenburg (2001) established the Fila-morph to be comprised of $O$. fila and O. parmula. The two species, however, turned out to be synonymous by a couple of population genetic studies (Andrade et al. 2012; Tulchinsky et al. 2012). Again, as Article 6.2 of the Code (ICZN 1999) provides that the Principle of Priority applies to such infra-subgeneric, su-
Table 2. Range and average (in parentheses) of Kimura 2-parameter distances among and between 'species' that were estimated by three different delimitation analysis methods (ABGD, PTP, TCS), based on a total of 487 sequences of COI gene ( $658 \mathrm{bp})$, of which 462 were available in GenBank and 25 were generated de novo in this study.

\begin{tabular}{lcc}
\hline & Intra-specific K2P distance & Inter-specific K2P distance \\
\hline ABGD & $0.000-0.036(0.007)$ & $0.063-0.292(0.164)$ \\
PTP & $0.000-0.024(0.004)$ & $0.015-0.278(0.160)$ \\
TCS & $0.000-0.014(0.004)$ & $0.011-0.258(0.162)$ \\
\hline
\end{tabular}

pra-specific names, we refer to this group as O. parmula because O. parmula Corrêa, 1950 has precedence over O. fila Corrêa, 1953. The group can be diagnosed as having polygranular statoliths, spirally-sculptured central stylet, short proboscis diaphragm, and bulbous proboscis middle chamber. It appears that in many species, the proboscis posterior chamber has a specialized anterior region, although it is not explicitly mentioned in the original descriptions of $O$. fila and O. parmula.

Further scrutiny is necessary to elucidate taxonomic identities for the Cirrula- and Pallida-morphs of Envall and Norenburg (2001), as well as a number of biological entities (presumably 'species') in what were identified as Erneba and Santacruzensis of Leasi et al. (2016), which, however, is beyond the scope of this paper. Species-group assignments of O. brevis Corrêa, 1948, O. cirrula Mock and Schmidt, 1975, O. erneba Corrêa, 1950, O. pallida (Keferstein, 1862), and O. santacruzensis Mock and Schmidt, 1975 remain uncertain for the time being.

\section{Results and Discussion}

\section{Species delimitation}

The ABGD analysis resulted in 46 groups, PTP in 65 entities, and TCS in 61 networks (Figs 2, 3). The average K2P distances among and between these 'species' (i.e., groups, entities, networks) were $0.004-0.007$ and $0.160-0.164$, respectively (Table 2). So-called barcoding gaps were not found in the PTP and TCS analyses, as the maximum intraspecific values exceeded the minimum inter-specific ones (Table 2).

The 25 individuals from Vietnam, of which COI sequences were available, were classified as seven groups/entities/ networks in all the three analyses. They are treated and described as distinct biological species in the following section.

\section{Taxonomy}

Ototyphlonemertes (duplex) chernyshevi sp. nov. (Fig. 4)

?Ototyphlonemertes (O.) cf. martynovi: Chernyshev 2007: 199, fig. 1f, g.

Material examined. Three specimens, all from Dam 


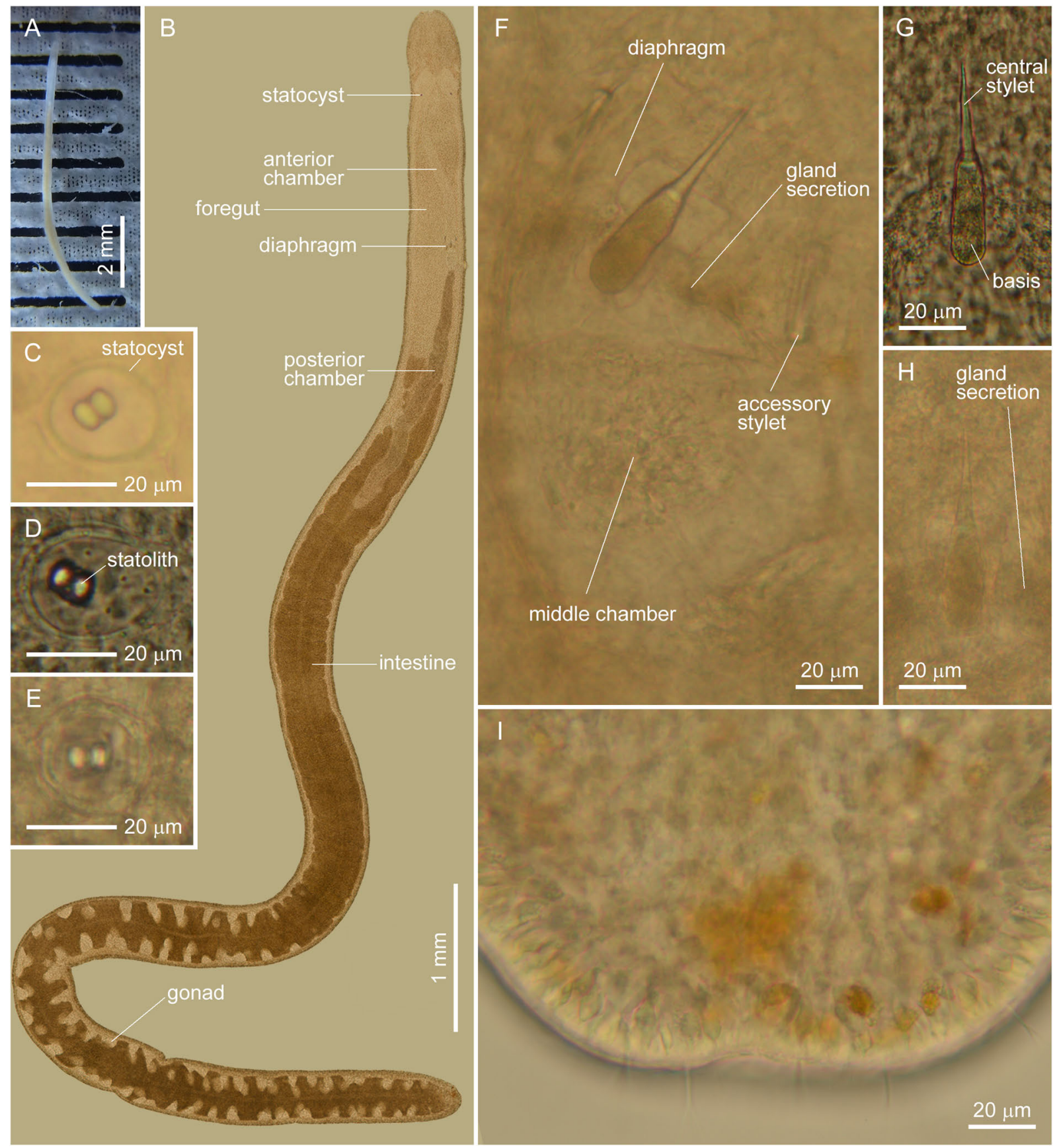

Fig. 4. Ototyphlonemertes (duplex) chernyshevi sp. nov. A, Entire body; B, composite photomicrograph of squeezed specimen; C-E, statoliths; F, stylet apparatus, G, H, central stylets and bases; I, posterior end of body. A, C, F, I, ICHUM 5348 (holotype); B, G, ICHUM 5349 (paratype); E, H, ICHUM 5350 (paratype).

Trong; ICHUM 5348 (holotype); ICHUM 5349, 5350 (two paratypes).

Description. Body length $8-12 \mathrm{~mm}$ ( $8 \mathrm{~mm}$ in holotype), width $0.2-0.3 \mathrm{~mm}(0.2 \mathrm{~mm}$ in holotype) $(n=3)$ (Fig. 4A, B). Epidermis whitish (Fig. 4A); cephalic furrow postcerebrally; tissues around brain reddish; cirri present on cephalic region and hind end of body. Statoliths two-partite (Fig. 4C-E), 10.2-11.7 $\mu \mathrm{m}$ in diameter (10.2 $\mu \mathrm{m}$ in holotype) $(n=3)$; statocyst $24.8-29.5 \mu \mathrm{m}$ in diameter $(24.8 \mu \mathrm{m}$ in holotype) $(n=3)$. Proboscis diaphragm short (Fig. 4 F); gland secretion ring situated anterior to hind end of basis; accessory stylet pouches two (Fig. $4 \mathrm{~F}$ ), each containing two ac- cessory stylets (directing either anteriorly or posteriorly), situated laterally to central-stylet basis; central stylet smooth (Fig. 4F-H), 28.2-33.6 $\mu \mathrm{m}$ long (33.6 $\mu \mathrm{m}$ in holotype); basis $26.2-30.8 \mu \mathrm{m}$ long $(30.8 \mu \mathrm{m}$ in holotype), $9.4-11.8 \mu \mathrm{m}$ wide $(11.8 \mu \mathrm{m}$ in holotype) $(n=3)$; basis length/width ratio 2.28 2.80 (2.61 in holotype) $(n=3)$; posterior chamber opaque, without specialized anterior portion. Intestinal diverticula shallow and sack-like. Posterior adhesive plate with cells containing orange contents (Fig. 4I).

Distribution. So far known only from the type locality, the island of Dam Trong, Vietnam.

Etymology. The specific name is a noun in the genitive 


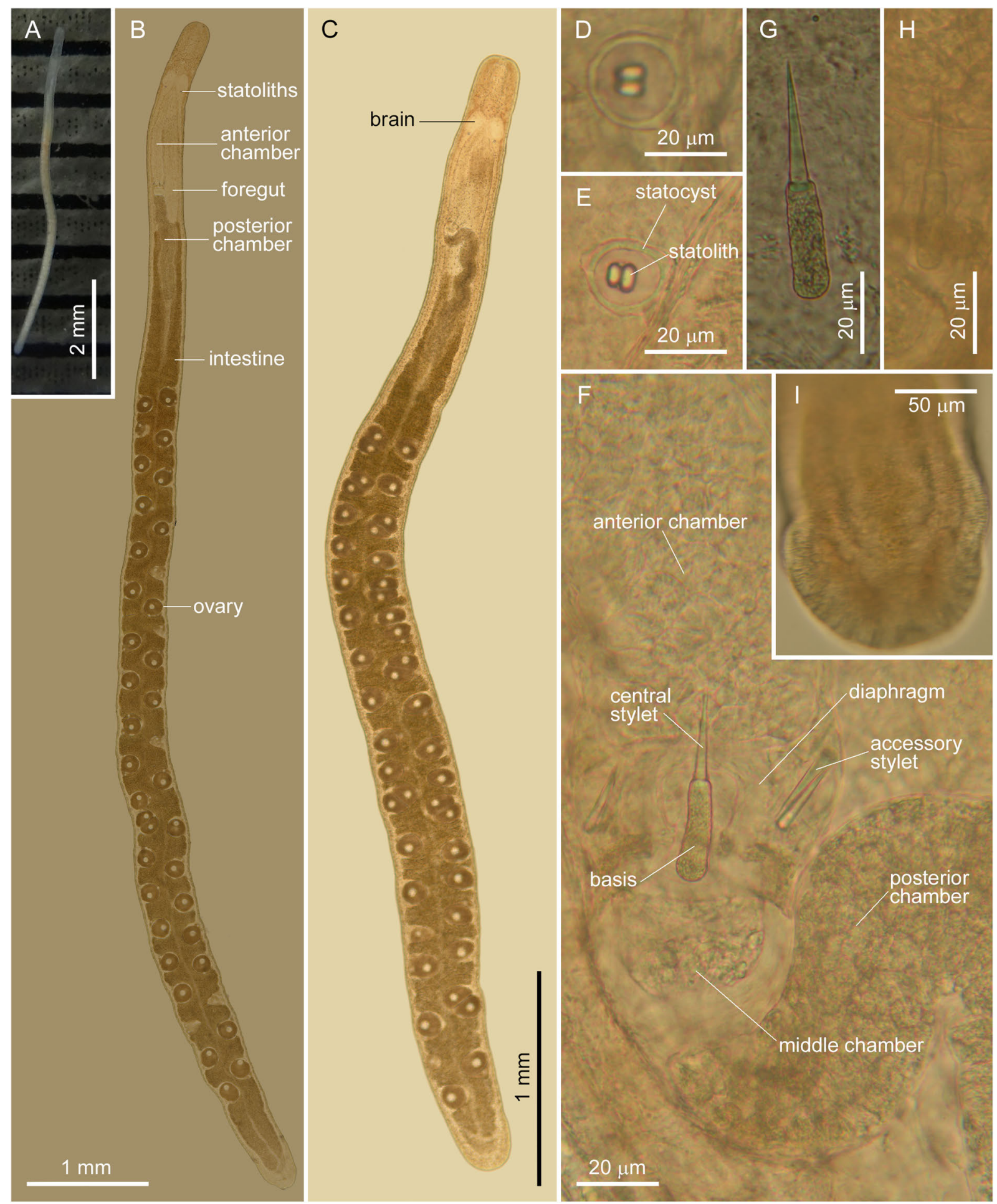

Fig. 5. Ototyphlonemertes (duplex) envalli sp. nov. A, Entire body; B, C, composite photomicrographs of squeezed specimens; D, E, statoliths; F, stylet apparatus; G, H, central stylets and bases; I, posterior end of body. A, B, D, G, ICHUM 5351 (jolotype); C, E, F, ICHUM 5353 (paratype); H, I, ICHUM 5352 (paratype).

case, after the distinguished nemertean biologist Professor Dr Alexei Viktorovich Chernyshev at A. V. Zhirmunsky Institute of Marine Biology, Far East Branch of Russian Academy of Science, and concurrently at Far Eastern Federal University, in recognition of his significant contribution to the nemertean systematics in general and, in particular, that of Ototyphlonemertes, as well as to clarification of Vietnamese nemertean fauna.

Remarks. Ototyphlonemertes (duplex) chernyshevi sp. nov. is similar to a specimen from Van Phong Bay, Vietnam $\left(12^{\circ} 39^{\prime} \mathrm{N}, 109^{\circ} 20^{\prime} \mathrm{E}\right)$, which was uncertainly identified as O. (duplex) martynovi by Chernyshev (2007), in that their stylet bases are thick and stumpy, by which they can be distinguished from $O$. (duplex) envalli sp. nov. and $O$. 


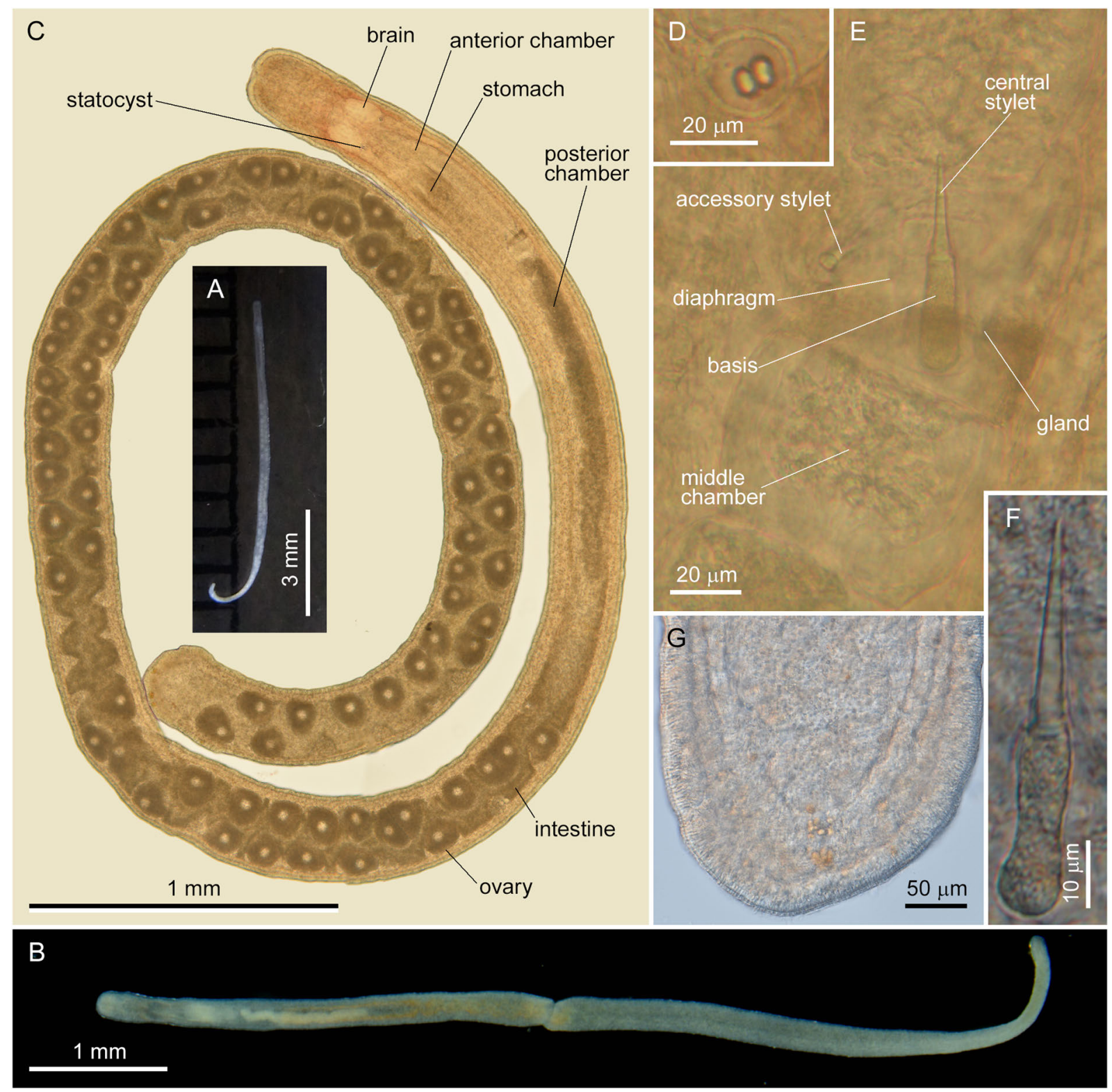

Fig. 6. Ototyphlonemertes (duplex) norenburgi sp. nov. A, B, Entire body; C, composite photomicrograph of squeezed specimen; D, statoliths; E, stylet apparatus; F, central stylet and basis; G, posterior end of body. A, C, D, E, ICHUM 5355 (holotype); B, F, G, ICHUM 5356 (paratype).

(duplex) norenburgi sp. nov.; the basis is thinner in the latter two in comparison with that of $O$. (duplex) chernyshevi. Our unpublished sequence data indicate that $O$. (duplex) chernyshevi is genetically different from $O$. (duplex) martynovi s.str. (14.89-16.29\% in uncorrected $p$-distance; 0.1869 0.2109 in $\mathrm{K} 2 \mathrm{P})$.

Ototyphlonemertes (duplex) envalli sp. nov. (Fig. 5)

Material examined. Four specimens, all from Dam Trong; ICHUM 5351 (holotype); ICHUM 5352-5354 (three paratypes).

Description. Body length $5.0-6.2 \mathrm{~mm}(6.2 \mathrm{~mm}$ in holotype), width $0.2 \mathrm{~mm}(n=3)$. Epidermis whitish (Fig. $5 \mathrm{~A})$; cephalic furrow post-cerebrally; tissues around brain red- dish (Fig. 5B, C); cirri present in both anterior and posterior ends of body. Foregut-intestine junction distinct; foregut region translucent; intestine tinged with pale-yellow to whitish color (Fig. 5A). Statoliths bipartite (Fig. 5D, E), $8.5-9.2 \mu \mathrm{m}$ in diameter $(8.5 \mu \mathrm{m}$ in holotype) $(n=3)$; statocyst $23.8-25.6 \mu \mathrm{m}$ in diameter $(23.8 \mu \mathrm{m}$ in holotype $)(n=3)$. Proboscis diaphragm short (Fig. 5F); two accessory stylet pouches, lateral to central-stylet basis, each containing two accessory stylets $(n=3)$; in two of three specimens examined, one of two accessory-stylet pouches contained one accessory stylet that directed backward; other accessory stylets directed forward; middle chamber bulbous (Fig. 5F); central stylet smooth (Fig. 5G, H), 23.9-31.6 $\mu \mathrm{m}$ long $(23.9 \mu \mathrm{m}$ in holotype); basis $29.6-31.6 \mu \mathrm{m}$ long $(29.6 \mu \mathrm{m}$ in holotype), $7.4-8.1 \mu \mathrm{m}$ wide $(7.4 \mu \mathrm{m}$ in holotype) $(n=3)$; basis length/ width ratio $3.90-4.00$ (4.00 in holotype) $(n=3)$; posterior 
chamber opaque, without specialized anterior portion (Fig. 5B, C, F). Intestinal diverticula shallow. Mature oocytes up to $136 \mu \mathrm{m}$ in diameter, accounting for $\sim 35 \%$ of body width (Fig. 5B, C). Posterior adhesive plate well developed (Fig. 5I).

Distribution. So far known only from the type locality, the island of Dam Trong, Vietnam.

Etymology. The specific name is a noun in the genitive case, after Dr Mats Envall for his distinguished contribution to the Ototyphlonemertes systematics.

Remarks. Ototyphlonemertes (duplex) envalli sp. nov. was sister to $O$. (duplex) norenburgi sp. nov. in the phylogenetic analysis (Fig. 2) and they look similar to each other. As far as the specimens observed, $O$. (duplex) envalli may be distinguished from $O$. (duplex) norenburgi in that the ratio of the oocyte diameter to the body width is smaller than in $O$. (duplex) envalli (oocyte / body-width ratio $~ 0.35$ ) than in $O$. (duplex) norenburgi (oocyte/body-width ratio $>0.4$ ). Whether or not this character is reliable in discriminating these two species should be investigated in future studies, because the degree of oocyte matureness might have been different among the specimens examined. Also, the squeezed method might have skewed the actual diameters of the body and oocytes.

\section{Ototyphlonemertes (duplex) norenburgi sp. nov.} (Fig. 6)

Material examined. Two specimens, both from Dam Ngoai; ICHUM 5355 (holotype); ICHUM 5356 (paratype).

Description. Body length $7.8 \mathrm{~mm}$ (paratype) to $9.0 \mathrm{~mm}$ (holotype), width $0.2 \mathrm{~mm}$ (paratype) to $0.3 \mathrm{~mm}$ (holotype) $(n=2)$. Epidermis whitish (Fig. 6A, B); cephalic furrow post-cerebrally; tissues around brain reddish (Fig. 6C); cirri present in both anterior and posterior ends of body. Foregut-intestine junction not distinct (intestinal caecum possibly present). Statoliths bipartite (Fig. 6D), $8.4 \mu \mathrm{m}$ (paratype) to $9.6 \mu \mathrm{m}$ (holotype) in diameter $(n=2)$; statocyst $27.9 \mu \mathrm{m}$ (holotype) to $30.5 \mu \mathrm{m}$ (paratype) in diameter $(n=2)$. Proboscis diaphragm short (Fig. 6E); two accessory stylet pouches, lateral to central-stylet basis, each containing 2-3 accessory stylets $(n=2)$; in holotype, one of two accessorystylet pouch contained three accessory stylets all directing forward; another accessory-stylet pouch contained two accessory stylets each directing forward and backward; paratype had two accessory stylets per pouch both directing forward; middle chamber bulbous; central stylet smooth (Fig. $6 \mathrm{E}, \mathrm{F}), 28.3 \mu \mathrm{m}$ (holotype) to $33.0 \mu \mathrm{m}$ (paratype) long; basis $26.4 \mu \mathrm{m}$ (paratype) to $29.1 \mu \mathrm{m}$ (holotype) long, $7.5 \mu \mathrm{m}$ (holotype) to $9.3 \mu \mathrm{m}$ (paratype) wide $(n=2)$; basis length width ratio 2.84 (paratype) to 3.88 (holotype) $(n=2)$; posterior chamber opaque, without specialized anterior portion. Intestinal diverticula shallow. Posterior adhesive plate containing cells with orange contents. Mature oocytes up to $70 \mu \mathrm{m}$ in diameter, accounting for more than $40 \%$ of body width (Fig. 6C).

Distribution. Our unpublished sequence data indicate that $O$. (duplex) norenburgi sp. nov. is also distributed in
Onnason, Okinawa-jima island, although it was recovered only from Dam Ngoai in the present study.

Etymology. The specific name is a noun in the genitive case, after the eminent nemertean biologist Dr Jon Laurence Norenburg at the Department of Invertebrate Zoology, National Museum of Natural History, Smithsonian Institution, USA, in respect of his distinguished achievement and contribution to the ribbon-worm systematics, including that of Ototyphlonemertes, as well as other interstitial animals.

Remarks. In the resulting phylogenetic tree, O. (duplex) norenburgi was sister to O. (duplex) envalli (Fig. 2). Morphologically, $O$. (duplex) norenburgi may be distinguished from $O$. (duplex) envalli by the larger oocyte size relative to the body width: the oocyte/body-width ratio exceeds 0.4 in $O$. (duplex) norenburgi, while it is around 0.35 in O. (duplex) envalli [but see Remarks for $O$. (duplex) envalli above]. From O. (duplex) chernyshevi, O. (duplex) norenburgi may be distinguished by its thinner stylet basis: the basis length/width ratio was $2.84-3.88$ in $O$. (duplex) norenburgi, while it was 2.28-2.80 in O. (duplex) chernyshevi.

\section{Ototyphlonemertes (macintoshi) ani Chernyshev, 2007 \\ (Fig. 7)}

Ototyphlonemertes (Norenburgia) ani Chernyshev, 2007: 196-199, figs 1, 2.

Ototyphlonemertes lactea (not of Corrêa 1954): Leasi et al. 2016: 1393, fig. 4a, network L3 $(139,160,180)$.

Material examined. Eight specimens, all from Dam Ngoai; ICHUM 5357-5364.

Description. Body length $4.3-11.0 \mathrm{~mm}$, width $0.3-$ $0.4 \mathrm{~mm}(n=8)$. Epidermis whitish (Fig. 7A), containing red pigment cells sporadically scattered among other epidermal cells; cephalic furrow post-cerebrally; tissues around brain reddish; cirri not found on cephalic region $(n=5), 5-7$ cirri found near hind end of body $(n=3)$. Foregut-intestine junction distinct (Fig. 7A, B). Statoliths polygranular (Fig. $7 \mathrm{C}-\mathrm{J}), 10.9-14.7 \mu \mathrm{m}$ in diameter $(n=8)$, consisting of about 22 granules; statocyst $20.9-30.4 \mu \mathrm{m}$ in diameter $(n=8)$; additional statolith found in one specimen on single side (Fig. 7C). Proboscis anterior chamber with tactile papillae (Fig. 7L); diaphragm long (Fig. 7K, L); two accessory-stylet pouches, lateral to central-stylet basis; 2-6 accessory stylets per pouch ( $n=8$ individuals $\times 2$ pouches), with mode being 5 (three individuals having 5 accessory stylets in each pouch; one individual with 4 and 5 accessory stylets, another with 5 and 6 accessory stylets); of 69 accessory stylets in 8 specimens, 2 in one specimen directed forward, other 67 directing backward; central stylet (as well as accessory stylets) spiral (Fig. 7M), 28.5-46.2 $\mu \mathrm{m}$ long; basis $27.7-33.3 \mu \mathrm{m}$ long, 4.1-6.5 $\mu \mathrm{m}$ wide $(n=8)$, with each ridge twisting almost only once; basis length/width ratio 4.58-6.5; middle chamber antero-posteriorly elongated rectangle (Fig. 7K), with prominent diagonal muscle fibers (Fig. 7L); posterior chamber vesicular, without specialized anterior portion. Intestinal diverticula shallow and sack-like. Posterior adhesive 


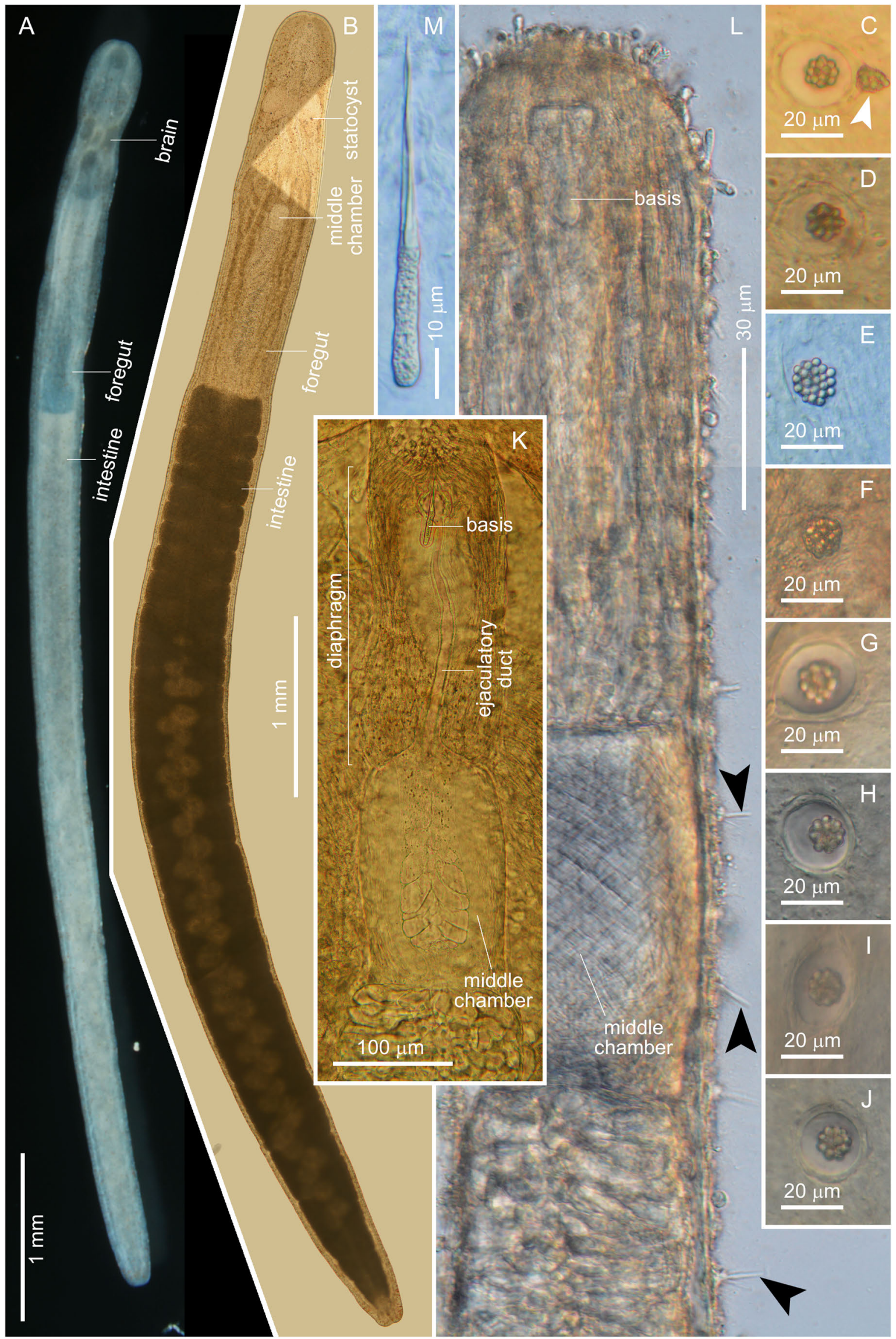

Fig. 7. Ototyphlonemertes (macintoshi) ani Chernyshev, 2007. A, Entire body; B, composite photomicrograph of squeezed specimen; C-J, statoliths (arrowhead on C indicates additional statolith); K, proboscis diaphragm and middle chamber; L, everted proboscis (arrowheads indicating rhabdoid-like papillae); M, central stylet and basis. A, E, M, ICHUM 5359; B, D, ICHUM 5358; C, K, ICHUM 5357; F, L, ICHUM 5360; G, ICHUM 5361; H, ICHUM 5362; I, ICHUM 5363; J, ICHUM 5364. 


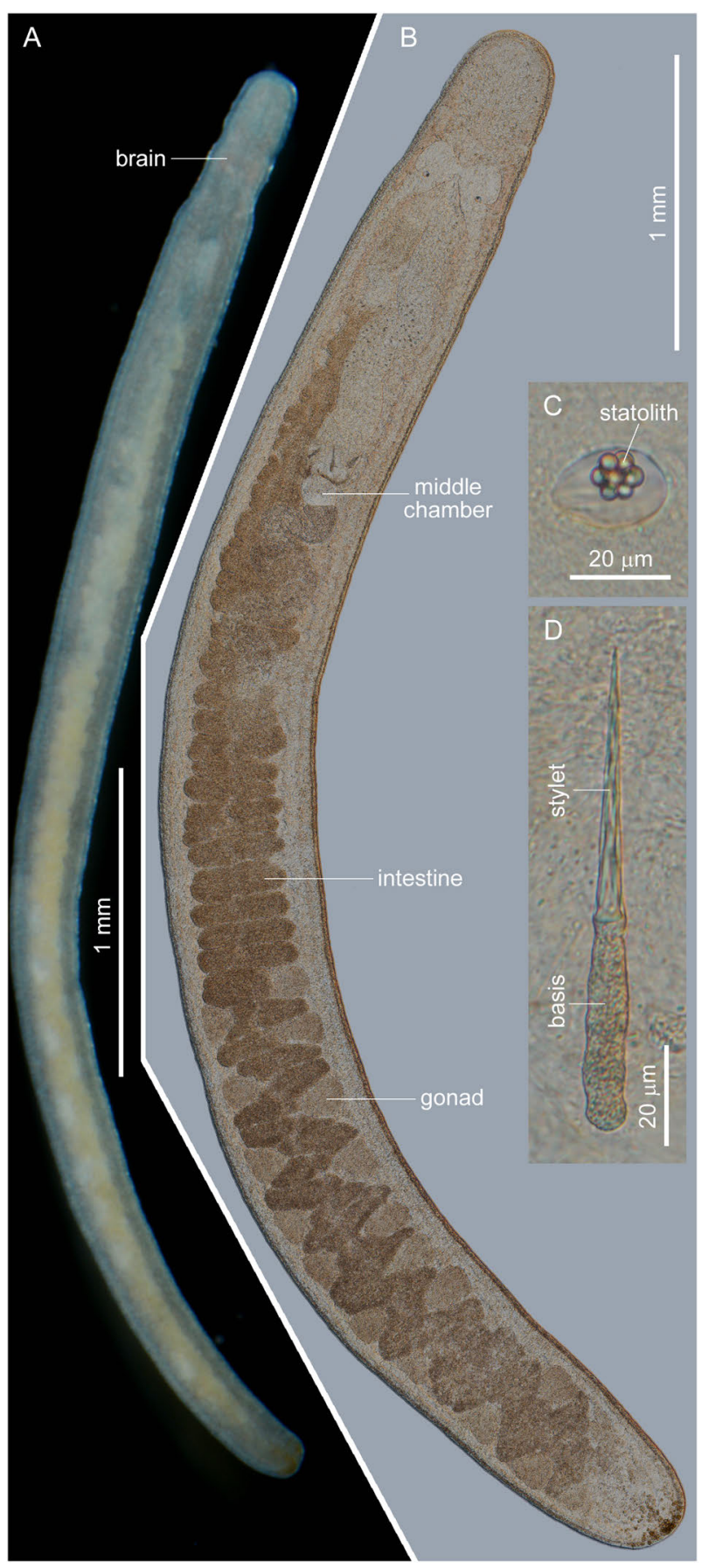

Fig. 8. Ototyphlonemertes (parmula) lei sp. nov., ICHUM 5365 (holotype). A, Entire body; B, composite photomicrograph of squeezed specimen; C, statolith; D, central stylet and basis.

plate with pale brown pigments.

Distribution. Tche Bay $\left(12^{\circ} 35^{\prime} \mathrm{N}, 109^{\circ} 20^{\prime} \mathrm{E}\right)$, HongLong Island, Van Phong Bay, Vietnam (Chernyshev 2007); Dam Ngoai, Vietnam (present study); Gesashi, Okinawa, Japan (Leasi et al. 2016); Shirahama, Japan (Leasi et al. 2016).

Remarks. In the molecular phylogenetic tree, O. ( $m a-$ cintoshi) ani was nested within a clade comprised of other OTUs representing the O. macintoshi species group (Fig. 3). The GenBank COI sequences KU230129 and KU230131 (from Shirahama, Japan: Leasi et al. 2016), as well as
KU230130 (from Gesashi, Okinawa, Japan: Leasi et al. 2016), all identified as Ototyphlonemertes lactea, turned out to represent $O$. (macintoshi) ani. It was the most abundant species in this study.

\section{Ototyphlonemertes (parmula) lei sp. nov.}

(Fig. 8)

Material examined. One specimen from Dam Ngoai; ICHUM 5365 (holotype).

Description. Body length $4.9 \mathrm{~mm}$, width $0.2 \mathrm{~mm}$ $(n=1)$. Epidermis whitish (Fig. 8A); cephalic furrow postcerebrally; tissues around brain slightly reddish; cirri present in both anterior and posterior ends of body. Foregut-intestine junction not distinct (Fig. 8B). Statolith polygranular (Fig. $8 \mathrm{C}$ ), $9.3 \mu \mathrm{m}$ in diameter $(n=1)$, consisting of about 7 granules; statocyst $15.9 \mu \mathrm{m}$ in diameter $(n=1)$. Proboscis diaphragm short (Fig. 8B); two accessory stylet pouches, lateral to central-stylet basis, each containing 4 and 5 accessory stylets, all directing forward; central stylet (as well as accessory stylets) spiral (Fig. 8D), $54.7 \mu \mathrm{m}$ long; basis $43.2 \mu \mathrm{m}$ long, $8.0 \mu \mathrm{m}$ wide (Fig. $8 \mathrm{D}$ ), with each ridge twisting about 1.5 times; basis length/width ratio 5.4; middle chamber short; posterior chamber vesicular, without specialized anterior portion (Fig. 8B). Intestinal diverticula deep. Posterior adhesive plate with cells containing dark contents. Gonads found in posterior half of intestinal region, alternating more or less regularly with intestinal lateral diverticula.

Distribution. So far known only from the type locality, the island of Dam Ngoai, Vietnam.

Etymology. The specific name is a noun in the genitive case, after Dr Doan Dung Le at the Ho Chi Minh City University of Food Industry, Vietnam, who kindly coordinated HK's sampling trip to Phu Quoc.

Remarks. In the phylogenetic tree, Ototyphlonemertes (parmula) lei sp. nov. appeared to be sister to the rest of the O. parmula species group (Fig. 2), which was mostly represented by the Fila morpho-group of Leasi et al. (2016).

\section{Ototyphlonemertes (parmula) nakaoae sp. nov.}

(Figs 9, 10)

Material examined. Five specimens: ICHUM 5366 (holotype) (from Dam Trong); four paratypes, ICHUM 5367 (from Dam Trong), ICHUM 5368-5370 (from Dam Ngoai).

Description. Body length $4.1-6.2 \mathrm{~mm}(6.2 \mathrm{~mm}$ in holotype), width $0.2-0.3 \mathrm{~mm}(0.2 \mathrm{~mm}$ in holotype $)(n=4)$. Epidermis whitish (Fig. 9A, D, E); cephalic furrow postcerebrally; tissues around brain slightly reddish (Figs 9B, E, F, 10A, B); cirri present in both anterior and posterior ends of body; cephalic cirrus formula ( $c f$. Norenburg 1988b) observed in two specimens: $A=2+2, B=0, C=9, D=6, E=4$, tail $=14$ in ICHUM 5368 (paratype); $\mathrm{A}=0, \mathrm{~B}=2, \mathrm{C}=7+5$, $\mathrm{D}=4+5$, tail $=8$ in ICHUM 5369 (paratype). Foregut-intestine junction not markedly distinct. Statolith polygranular (Fig. 10C-F), $8-11 \mu \mathrm{m}(9 \mu \mathrm{m}$ in holotype) in diameter $(n=4)$, consisting of 7-8 (7 in holotype) granules; statocyst $19.2-26.1 \mu \mathrm{m}(19.2 \mu \mathrm{m}$ in holotype $)$ in diameter $(n=4)$. Pro- 


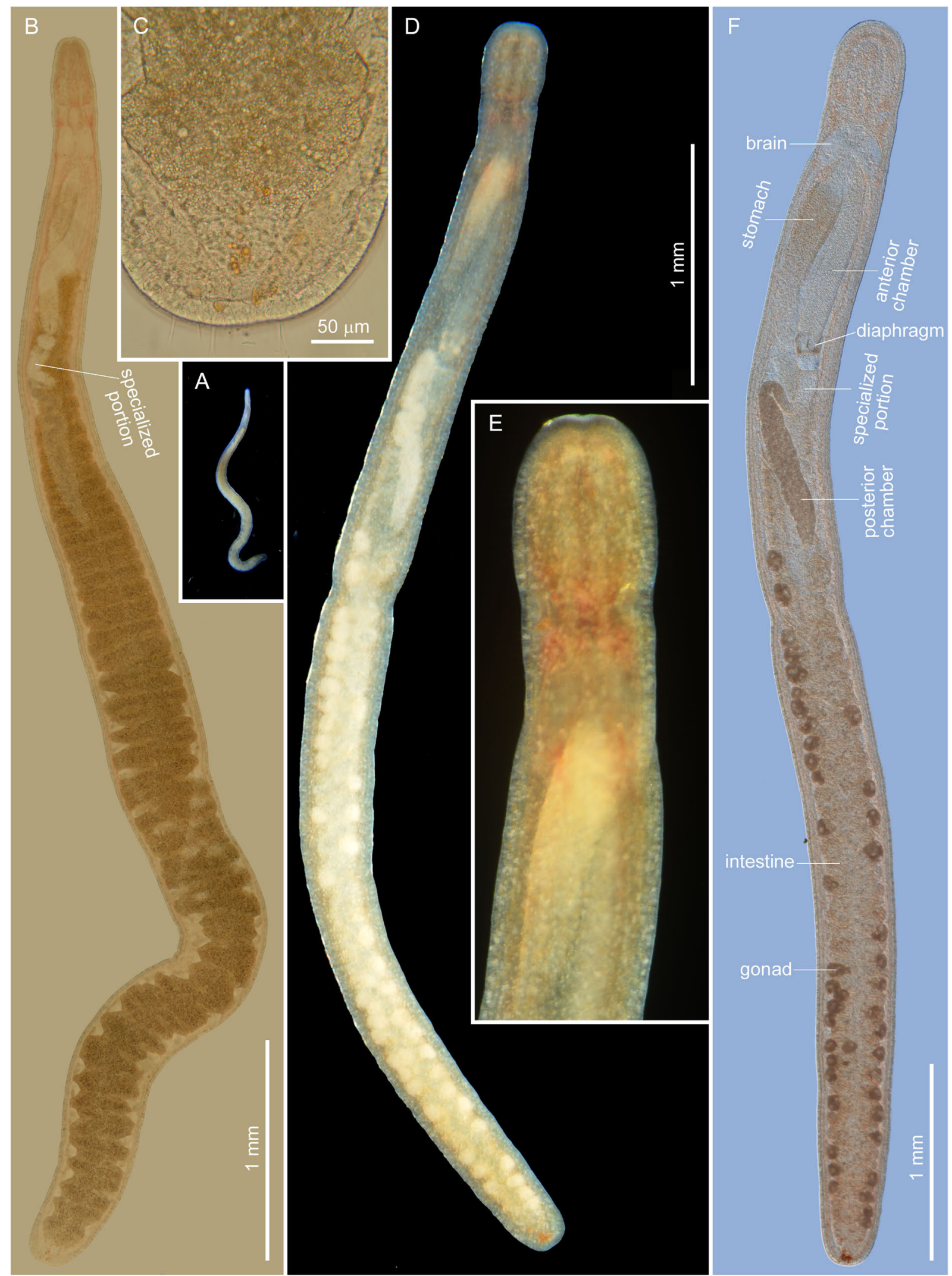

Fig. 9. Ototyphlonemertes (parmula) nakaoae sp. nov. A, D, Entire body; B, F, composite photomicrographs of squeezed specimens; C, posterior end of body; E, enlargement of head, anaesthetized specimen. A-C, ICHUM 5366 (holotype); D-F, ICHUM 5368 (paratype).

boscis diaphragm short (Figs 9F, 10A, B, G); gland-secretion ring situated posterior to hind end of basis; accessory-stylet pouches two, each containing 2-5 accessory stylets (3 in each in holotype) per pouch ( $n=4$ individuals $\times 2$ pouches), directing both forward and backward; central stylet (as well as accessory stylets) spiral (Fig. 10H-K), 32-46 $\mu \mathrm{m}(32 \mu \mathrm{m}$ 


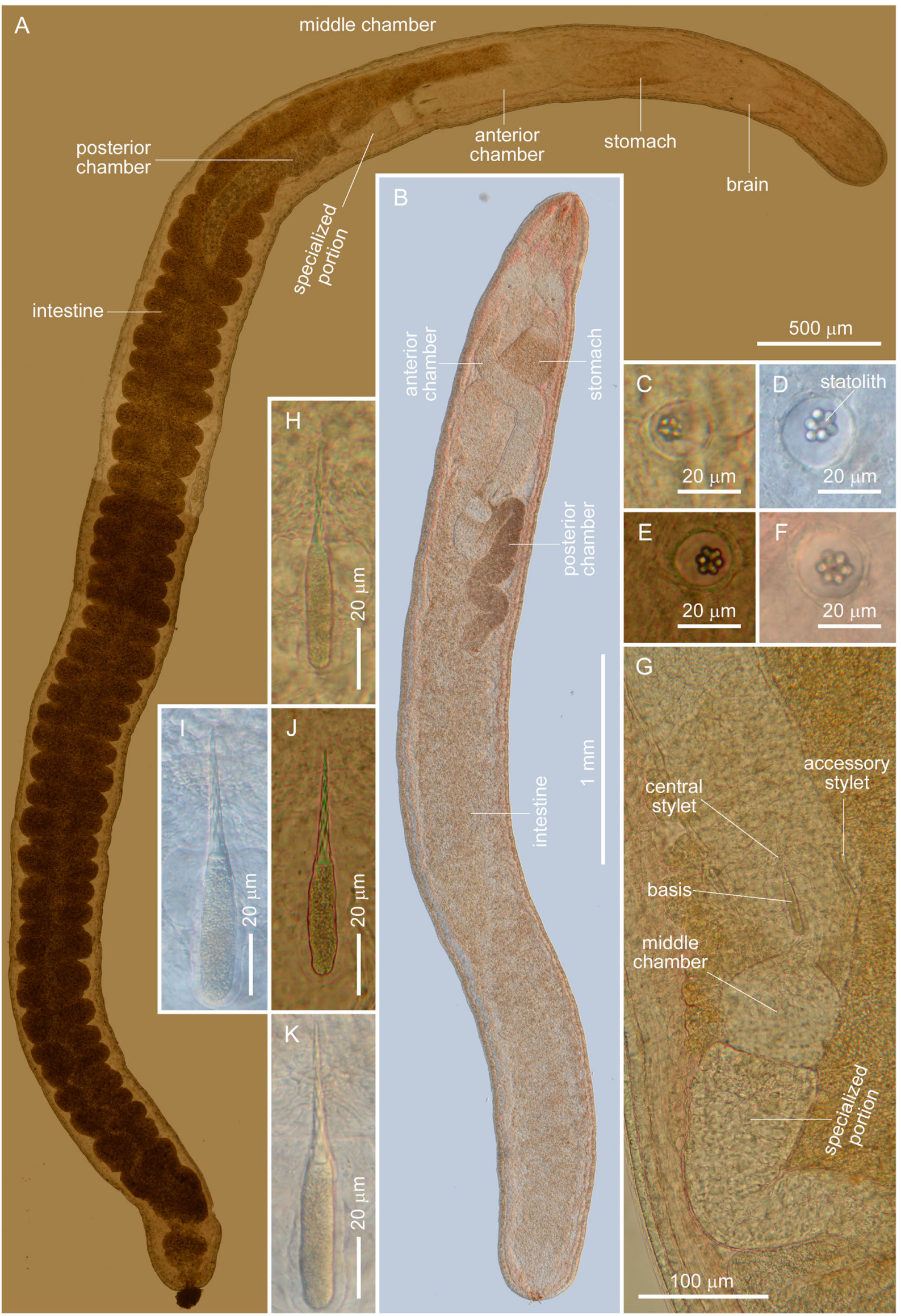

Fig. 10. Ototyphlonemertes (parmula) nakaoae sp. nov. A, B, Composite photomicrographs of squeezed specimens; C-F, statoliths; G, stylet apparatus; H-K, central stylets and bases. A, E, J, ICHUM 5367 (paratype); B, F, K, ICHUM 5369 (paratype); C, G, H, ICHUM 5366 (holotype); D, I, ICHUM 5368 (paratype). 

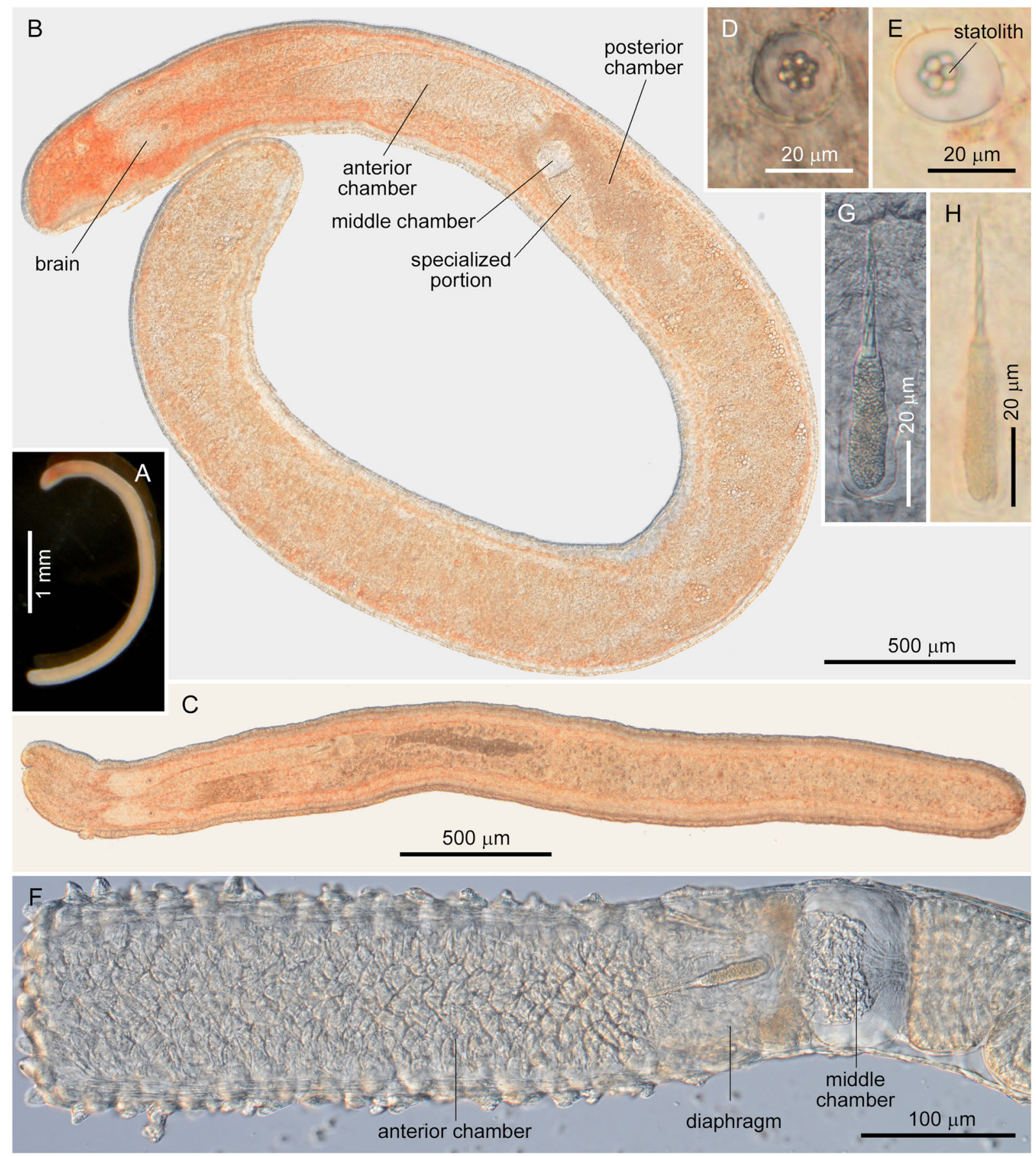

Fig. 11. Ototyphlonemertes (parmula) tsukagoshii sp. nov. A, Entire body; B, C, composite photomicrographs of squeezed specimens; D, E, statoliths; F, partially everted proboscis; G, H, central stylets and bases. A, B, D, F, G, ICHUM 5371 (holotype); C, E, H, ICHUM 5372 (paratype).

in holotype) long; basis $39-52 \mu \mathrm{m}$ ( $42 \mu \mathrm{m}$ in holotype) long, $8-12 \mu \mathrm{m}(8 \mu \mathrm{m}$ in holotype) wide $(n=4)$, with each ridge twisting 1.5-2 (1.5 in holotype) times; basis length/width ratio 4.27-5.16 (5.16 in holotype); middle chamber bulbous; posterior chamber opaque, with specialized anterior part (Figs 9B, F, 10A, B). Intestinal diverticula deep. Posterior adhesive plate containing cells with orange contents (Fig. 9C). Gonads found in posterior $1 / 2$ to $3 / 4$ of intestinal region, alternating more or less regularly with intestinal lateral diverticula.

Distribution. So far recorded from the islands of Dam
Trong (type locality) and Dam Ngoai, Vietnam.

Etymology. The specific name is a noun in the genitive case, after the Japanese ostracode biologist Dr Yuriko Nakao at Nihon University, Japan, who devotedly arranged our sampling trip to Phu Quoc.

Remarks. In the phylogenetic tree, Ototyphlonemertes (parmula) nakaoae sp. nov. was sister to O. (parmula) tsukagoshii sp. nov. (Fig. 2). Out of the seven species discovered in this study, O. (parmula) nakaoae turned out to be the only species that occurred at both the localities surveyed, the islands of Dam Trong and Dam Ngoai. Following $O$. 
(macintoshi) ani, it was the second most abundant species recovered in the present survey.

\section{Ototyphlonemertes (parmula) tsukagoshii sp. nov.}

(Fig. 11)

Material examined. Two specimens, both from Dam Ngoai; ICHUM 5371 (holotype); ICHUM 5372 (paratype).

Description. Body length $2.5 \mathrm{~mm}$ (paratype) to $4.0 \mathrm{~mm}$ (holotype), width $0.1 \mathrm{~mm}$ (paratype) to $0.2 \mathrm{~mm}$ (holotype) $(n=2)$. Epidermis whitish (Fig. 11A); cephalic furrow postcerebrally; tissues around brain (and even in precerebral region in one of two specimens examined) reddish (Fig. 11B, C); cirri present in both anterior and posterior ends of body; cephalic cirrus formula ( $c f$. Norenburg 1988b) observed in two specimens: $A=2, B=0, C=8, D=$ ?, $E=$ ?, tail $=12$ in holotype; $\mathrm{A}=2, \mathrm{~B}=0, \mathrm{C}=5+6, \mathrm{D}=6+10, \mathrm{E}=3$, tail $=10$ in paratype. Foregut-intestine junction indistinct. Statolith polygranular (Fig. $11 \mathrm{D}, \mathrm{E}), 9.5 \mu \mathrm{m}$ in diameter $(n=2)$, consisting of 6 granules; statocyst $23.5 \mu \mathrm{m}$ (holotype) to $28.4 \mu \mathrm{m}$ (paratype) in diameter $(n=2)$. Proboscis anterior chamber with wart-like papillae (Fig. 11F); diaphragm short (Fig. $11 \mathrm{~F}$ ); gland secretion ring situated posterior to hind end of basis; accessory-stylet pouches two, each containing 2-3 accessory stylets directing both forward and backward; central stylet (as well as accessory stylets) spiral (Fig. 11G, H), $35.0 \mu \mathrm{m}$ (paratype) to $40.2 \mu \mathrm{m}$ (holotype) long; basis $37.1 \mu \mathrm{m}$ (paratype) to $40.2 \mu \mathrm{m}$ (holotype) long, $8.3 \mu \mathrm{m}$ (paratype) to $11.2 \mu \mathrm{m}$ (holotype) wide $(n=2)$, with each ridge twisting 3 times; basis length/width ratio 3.59 (holotype) to 4.47 (paratype); middle chamber bulbous (Fig. 11F); posterior chamber opaque, with specialized anterior part (Fig. 11B, C). Intestinal diverticula deep. Posterior adhesive plate containing cells with orange contents.

Distribution. So far only recorded from the type locality, Dam Ngoai, Vietnam.

Etymology. The specific name is a noun in the genitive case, after the Japanese ostracode systematist Professor Akira Tsukagoshi at Shizuoka University, Japan, who organized our sampling trip to Phu Quoc.

Remarks. In the phylogenetic tree, Ototyphlonemertes (parmula) tsukagoshii sp. nov. was sister to O. (parmula) nakaoae sp. nov. (Fig. 2). Ototyphlonemertes (parmula) tsukagoshii differs from $O$. (parmula) nakaoae by the smaller body length (2.5-4.0 $\mathrm{mm} v s .4 .1-6.2 \mathrm{~mm})$, fewer number of statolith granules (6vs. 7-8), and greater number of styletridge twists (3 vs. 1.5-2). Also, O. (parmula) tsukagoshii tends to be more reddish in the external appearance, especially in the brain region, than $O$. (parmula) nakaoae.

\section{Conclusion}

Based on light microscopical observation of squeezed material and COI sequence data, we report seven, including six new, species of mesopsammic monostiliferans in the genus Ototyphlonemertes from two beaches, about $400 \mathrm{~m}$ apart, each in the island of Dam Trong and Dam Ngoai, situated to the south of Phu Quoc, southern Vietnam. None of eight localities investigated for meiobenthos around the main island of Phu Quoc yielded Ototyphlonemertes sample. Discovered from the material include three species from Dam Trong-O. (duplex) chernyshevi, O. (duplex) envalli, and $O$. (parmula) nakaoae-and five species from Dam Ngoai-O. (duplex) norenburgi, O. (macintoshi) ani, O. (parmula) lei, O. (parmula) nakaoae, and O. (parmula) tsukagoshii. These species fell into three morpho-types (cf. Envall and Norenburg 2001), which we placed at an infra-generic, supra-specific rank as 'species group' in a Code-compliant manner. Except for one group that was represented by a single species, viz., O. (macintoshi) ani, the species within each group were hardly distinguishable from each other solely based on morphological characters. Subtle morphological differences were observed between them, but whether these characters can be consistently and reliably used to discriminate the species has not been clarified in this study due to the limited number of samples, an issue that should be investigated in future studies. For the moment, DNA taxonomy is indispensable in understanding Ototyphlonemertes diversity, as has been previously demonstrated (e.g., Leasi and Norenburg 2014; Leasi et al. 2016).

\section{Acknowledgments}

HK is grateful to Professor Akira Tsukagoshi (Shizuoka University), Dr Doan Dung Le (Ho Chi Minh City University of Food Industry), Dr Yuriko Nakao (Nihon University), Dr Toshihiko Fujita (National Museum of Nature and Science), Dr Hiroshi Yamasaki (Leibniz Institute for Evolution and Biodiversity), Dr Hayato Tanaka (The University of Tokyo), and staffs at the Department of Marine Conservation, Research Institute for Marine Fisheries (which is Dr Le's former affiliation) for their kind help during the sampling trip to Phu Quoc. This study was financially supported by JSPS KAKENHI Grant Number JP26304011 for HK (Principal Investigator: Akira Tsukagoshi). All the specimens used in this study were collected in an agreement reached on 2 October 2014 between the Research Institute for Marine Fisheries (Vietnam) and Shizuoka University (Japan) under mutually agreed terms for access and benefitsharing. HK is thankful to Dr Jon L. Norenburg (Smithsonian National Museum of Natural History) for his expertise and technical advice for Ototyphlonemertes research in general. We are grateful to two anonymous reviewers for their constructive comments.

\section{References}

Andrade, S. C. S., Strand, M., Schwartz, M., Chen, H., Kajihara, H., Döhren, J. von, Sun, S., Junoy, J., Thiel, M., Norenburg, J. L., Turbeville, J. M., Giribet, G., and Sundberg, P. 2012. Disentangling ribbon worm relationships: multi-locus analysis supports traditional classification of the phylum Nemertea. Cladistics 28: 141159. 
Boom, R., Sol, C. J. A., Salimans, M. M. M., Jansen, C. L., Wertheimvan Dillen, P. M. E., and Van der Noordaa, J. 1990. Rapid and simple method for purification of nucleic acids. Journal of Clinical Microbiology 28: 495-503.

Bürger, O. 1895. Die Nemertinen des Golfes von Neapel und der angrenzenden Meeres-Abschnitte. Fauna und Flora des Golfes von Neapel und der angrenzenden Meeres-Abschnitte, 22, Monographie. R. Friedländer \& Sohn, Berlin, xvi+743 pp, 31 pls.

Chernyshev, A. V. 1993. Ototyphlonemertes martynovi sp. n. (Enopla, Ototyphlonemertidae) novaya interstitsialnaya nemertina iz yaponskogo morya. Zoologicheskii Zhurnal 72: 5-8.

Chernyshev, A. V. 1998. New data on interstitial nemerteans of the family Ototyphlonemertidae (Enopla, Monostilifera) from the Sea of Japan. Zoologicheskii Zhurnal 77: 266-269.

Chernyshev, A. V. 2007. Nemerteans of the genus Ototyphlonemertes (Enopla: Ototyphlonemertidae) from Van Phong Bay (South Vietnam). Russian Journal of Marine Biology 33: 196-199.

Chernyshev, A. V. 2011. Nemertean worms (Nemertea) of the Vietnamese coastal waters. Pp. 21-25. In: Lutaenko, K. A. (Ed.) Proceedings of the Workshop "Coastal Marine Biodiversity and Bioresources of Vietnam and Adjacent Areas to the South China Sea", Nha Trang, Vietnam, November 24-25, 2011. Dalnauka, Vladivostok, Nha Trang.

Chernyshev, A. V. 2016. Nemerteans of the coastal waters of Vietnam. Pp. 279-314. In: Adrianov, A. V. and Lutaenko, K. A. (Eds) Biodiversity of the Western Part of the South China Sea. Dalnauka, Vladivostok.

Clement, M., Posada, D., and Crandall, K. A. 2000. TCS: a computer program to estimate gene genealogies. Molecular Ecology 9: 1657-1659.

Corrêa, D. D. 1953. Sôbre a neurofisiologia locomotora de hoplonemertinos e a taxonomia de Ototyphlonemertes. Anais da Academia Brasileira de Ciéncias 25: 545-555.

Corrêa, D. D. 1954. Nemertinos do litoral Brasileiro. Boletim da Faculdade de Filosofia, Ciências e Letras, Universidade de São Paulo 19: 1-90.

Dawydoff, C. 1940. Les formes larvaires de polyclades et de némertes du plancton Indochinois. Bulletin Biologique de la France et de la Belgique 74: 443-496.

Dawydoff, C. 1952. Contribution a létude des invertébrés de la faune marine benthique de l'Indochine. Bulletin Biologique de la France et de la Belgique, Supplement 39: 1-158.

Envall, M. 1996. Ototyphlonemertes correae sp. nov. and a redescription of O. duplex (Nemertea: Monostilifera: Ototyphlonemertidae), with a phylogenetic consideration of the genus. Journal of Zoology 238: 253-277.

Envall, M. and Norenburg, J. L. 2001. Morphology and systematics in mesopsammic nemerteans of the genus Ototyphlonemertes ( $\mathrm{Ne}$ mertea, Hoplonemertea, Ototyphlonemertidae). Hydrobiologia 456: 145-163.

Folmer, O., Black, M., Hoeh, W., Lutz, R., and Vrijenhoek, R. 1994. DNA primers for amplification of mitochondrial cytochrome $c$ oxidase subunit I from diverse metazoan invertebrates. Molecular Marine Biology and Biotechnology 3: 294-299.

Fontaneto, D., Flot, J.-F., and Tang, C. Q. 2015. Guidelines for DNA taxonomy, with a focus on the meiofauna. Marine Biodiversity 45 : 433-451.

Gibson, R. 1985. The need for a standard approach to taxonomic descriptions of nemerteans. American Zoologist 25: 5-14.

Gibson, R. 1995. Nemertean genera and species of the world: an annotated checklist of original names and description citations, synonyms, current taxonomic status, habitats and recorded zoogeographic distribution. Journal of Natural History 29: 271-561.

International Commission on Zoological Nomenclature. 1999. Interna- tional Code of Zoological Nomenclature, Fourth Edition. International Trust for Zoological Nomenclature, London, xxix $+306 \mathrm{pp}$.

Joubin, L. 1905. Note sur un némertien recueilli au Tonkin par M. L. Boutan. Bulletin de la Société Zoologique de France 32: 145-147.

Kajihara, H. 2007. Ototyphlonemertes dolichobasis sp. nov. (Nemertea: Hoplonemertea: Monostilifera: Ototyphlonemertidae), a new species of interstitial nemertean from Japan. Species Diversity 12: $57-66$.

Kajihara, H. 2015. A histology-free description of the branched-proboscis ribbonworm Gorgonorhynchus albocinctus sp. nov. (Nemertea: Heteronemertea). Publications of the Seto Marine Biological Laboratory 43: 92-102.

Kajihara, H., Chernyshev, A. V., Sun, S.-C., Sundberg, P., and Crandall, F. B. 2008. Checklist of nemertean genera and species published between 1995 and 2007. Species Diversity 13: 245-274.

Kirsteuer, E. 1967. Marine, benthonic nemerteans: how to collect and preserve them. American Museums Novitates 2290: 1-10.

Kirsteuer, E. 1977. Remarks on taxonomy and geographic distribution of the genus Ototyphlonemertes Diesing (Nemertina, Monostilifera). Mikrofauna Meeresboden 61: 167-181.

Kvist, S., Laumer, C. E., Junoy, J., and Giribet, G. 2014. New insights into the phylogeny, systematics and DNA barcoding of Nemertea. Invertebrate Systematics 28: 287-308.

Leasi, F., Andrade, S. C. S., and Norenburg, J. 2016. At least some meiofaunal species are not everywhere. Indication of geographic, ecological and geological barriers affecting the dispersion of species of Ototyphlonemertes (Nemertea, Hoplonemertea). Molecular Ecology 25: 1381-1397.

Leasi, F. and Norenburg, J. L. 2014. The necessity of DNA taxonomy to reveal cryptic diversity and spatial distribution of meiofauna, with a focus on Nemertea. PLoS ONE 9: e104385.

Norenburg, J. L. 1988a. Nemertina. Pp. 287-292. In: Higgins, R. P. and Thiel, H. (Eds) Introduction to the Study of Meiofauna. Smithsonian Institution Press, Washington, D.C.

Norenburg, J. L. 1988b. Remarks on marine interstitial nemertines and key to the species. Hydrobiologia 156: 87-92.

Norenburg, J. L. and Gibson, R. 2012. Ototyphlonemertes Diesing, 1863. In: Norenburg, J., Gibson, R., Herrera Bachiller, A., and Strand, M. 2017. World Nemertea Database. Accessed through: World Register of Marine Species. Available at http://marinespecies.org/aphia. php/aphia.php? $\mathrm{p}=$ taxdetails\&id $=122408$ (7 November 2017).

Puillandre, N., Lambert, A., Brouillet, S., and Achaz, G. 2012. ABGD, automatic barcode gap discovery for primary species delimitation. Molecular Ecology 21: 1864-1877.

Stamatakis, A. 2014. RAxML version 8: a tool for phylogenetic analysis and post-analysis of large phylogenies. Bioinformatics 30: 13121313.

Strand, M. and Sundberg, P. 2011. A DNA-based description of a new nemertean (phylum Nemertea) species. Marine Biology Research 7: 63-70.

Tamura, K., Stecher, G., Peterson, D., Filipski, A., and Kumar, S. 2013. MEGA6: molecular evolutionary genetics analysis version 6.0. Molecular Biology and Evolution 30: 2725-2729.

Templeton, A. R., Crandall, K. A., and Sing, C. F. 1992. A cladistic analysis of phenotypic associations with haplotypes inferred from restriction endonuclease mapping and DNA sequence data. III. Cladogram estimation. Genetics 132: 619-633.

Tulchinsky, A. Y., Norenburg, J. L., and Turbeville, J. M. 2012. Phylogeography of the marine interstitial nemertean Ototyphlonemertes parmula (Nemertea, Hoplonemertea) reveals cryptic diversity and high dispersal potential. Marine Biology 159: 661-674.

Zhang, J., Kapli, P., Pavlidis, P., and Stamatakis, A. 2013. A general species delimitation method with applications to phylogenetic placements. Bioinformatics 29: 2869-2876. 
Appendix

List of DDBJ/EMBL/GenBank accession numbers of COI sequences used for the species delimitation analyses performed in the present study, with the species names that are $i$ ) originally registered in DDBJ/EMBL/GenBank and ii) used in this paper based on the results of the species delimitation analyses.

\begin{tabular}{|c|c|c|c|}
\hline $\begin{array}{l}\text { Accession } \\
\text { number }\end{array}$ & $\begin{array}{l}\text { Species name registered in } \\
\text { DDBJ/EMBL/GenBank }\end{array}$ & Species name used in this paper & Source \\
\hline LC310990 & Ototyphlonemertes chernyshevi & Ototyphlonemertes (duplex) chernyshevi & present study \\
\hline LC310991 & Ototyphlonemertes chernyshevi & Ototyphlonemertes (duplex) chernyshevi & present study \\
\hline LC310992 & Ototyphlonemertes chernyshevi & Ototyphlonemertes (duplex) chernyshevi & present study \\
\hline KU840025 & Ototyphlonemertes correae & Ototyphlonemertes (duplex) duplex & Leasi et al. (2016) \\
\hline KU840024 & Ototyphlonemertes correae & Ototyphlonemertes (duplex) duplex & Leasi et al. (2016) \\
\hline KU840023 & Ototyphlonemertes correae & Ototyphlonemertes (duplex) duplex & Leasi et al. (2016) \\
\hline KU840022 & Ototyphlonemertes correae & Ototyphlonemertes (duplex) duplex & Leasi et al. (2016) \\
\hline KU840021 & Ototyphlonemertes correae & Ototyphlonemertes (duplex) duplex & Leasi et al. (2016) \\
\hline KU840020 & Ototyphlonemertes correae & Ototyphlonemertes (duplex) duplex & Leasi et al. (2016) \\
\hline KU840016 & Ototyphlonemertes correae & Ototyphlonemertes (duplex) duplex & Leasi et al. (2016) \\
\hline KU230230 & Ototyphlonemertes duplex & Ototyphlonemertes (duplex) duplex & Leasi et al. (2016) \\
\hline KU230229 & Ototyphlonemertes correae & Ototyphlonemertes (duplex) duplex & Leasi et al. (2016) \\
\hline KU230228 & Ototyphlonemertes duplex & Ototyphlonemertes (duplex) duplex & Leasi et al. (2016) \\
\hline KU230227 & Ototyphlonemertes duplex & Ototyphlonemertes (duplex) duplex & Leasi et al. (2016) \\
\hline KU230226 & Ototyphlonemertes duplex & Ototyphlonemertes (duplex) duplex & Leasi et al. (2016) \\
\hline KU230225 & Ototyphlonemertes duplex & Ototyphlonemertes (duplex) duplex & Leasi et al. (2016) \\
\hline KU230224 & Ototyphlonemertes duplex & Ototyphlonemertes (duplex) duplex & Leasi et al. (2016) \\
\hline KU230223 & Ototyphlonemertes duplex & Ototyphlonemertes (duplex) duplex & Leasi et al. (2016) \\
\hline KU230222 & Ototyphlonemertes duplex & Ototyphlonemertes (duplex) duplex & Leasi et al. (2016) \\
\hline KU230221 & Ototyphlonemertes duplex & Ototyphlonemertes (duplex) duplex & Leasi et al. (2016) \\
\hline KU230220 & Ototyphlonemertes duplex & Ototyphlonemertes (duplex) duplex & Leasi et al. (2016) \\
\hline KU230219 & Ototyphlonemertes duplex & Ototyphlonemertes (duplex) duplex & Leasi et al. (2016) \\
\hline KU230218 & Ototyphlonemertes duplex & Ototyphlonemertes (duplex) duplex & Leasi et al. (2016) \\
\hline KU230217 & Ototyphlonemertes duplex & Ototyphlonemertes (duplex) duplex & Leasi et al. (2016) \\
\hline KU230216 & Ototyphlonemertes duplex & Ototyphlonemertes (duplex) duplex & Leasi et al. (2016) \\
\hline KU230215 & Ototyphlonemertes duplex & Ototyphlonemertes (duplex) duplex & Leasi et al. (2016) \\
\hline KU230214 & Ototyphlonemertes duplex & Ototyphlonemertes (duplex) duplex & Leasi et al. (2016) \\
\hline KU230213 & Ototyphlonemertes duplex & Ototyphlonemertes (duplex) duplex & Leasi et al. (2016) \\
\hline KU230212 & Ototyphlonemertes duplex & Ototyphlonemertes (duplex) duplex & Leasi et al. (2016) \\
\hline KU230211 & Ototyphlonemertes duplex & Ototyphlonemertes (duplex) duplex & Leasi et al. (2016) \\
\hline KU230210 & Ototyphlonemertes duplex & Ototyphlonemertes (duplex) duplex & Leasi et al. (2016) \\
\hline KU230209 & Ototyphlonemertes duplex & Ototyphlonemertes (duplex) duplex & Leasi et al. (2016) \\
\hline KU230208 & Ototyphlonemertes duplex & Ototyphlonemertes (duplex) duplex & Leasi et al. (2016) \\
\hline KU230207 & Ototyphlonemertes correae & Ototyphlonemertes (duplex) duplex & Leasi et al. (2016) \\
\hline KU230206 & Ototyphlonemertes correae & Ototyphlonemertes (duplex) duplex & Leasi et al. (2016) \\
\hline KU230205 & Ototyphlonemertes correae & Ototyphlonemertes (duplex) duplex & Leasi et al. (2016) \\
\hline KU230204 & Ototyphlonemertes correae & Ototyphlonemertes (duplex) duplex & Leasi et al. (2016) \\
\hline KU230203 & Ototyphlonemertes duplex & Ototyphlonemertes (duplex) duplex & Leasi et al. (2016) \\
\hline KU230202 & Ototyphlonemertes duplex & Ototyphlonemertes (duplex) duplex & Leasi et al. (2016) \\
\hline KU230201 & Ototyphlonemertes duplex & Ototyphlonemertes (duplex) duplex & Leasi et al. (2016) \\
\hline KU230200 & Ototyphlonemertes duplex & Ototyphlonemertes (duplex) duplex & Leasi et al. (2016) \\
\hline KU230199 & Ototyphlonemertes duplex & Ototyphlonemertes (duplex) duplex & Leasi et al. (2016) \\
\hline KU230198 & Ototyphlonemertes duplex & Ototyphlonemertes (duplex) duplex & Leasi et al. (2016) \\
\hline KU230197 & Ototyphlonemertes duplex & Ototyphlonemertes (duplex) duplex & Leasi et al. (2016) \\
\hline KU230196 & Ototyphlonemertes duplex & Ototyphlonemertes (duplex) duplex & Leasi et al. (2016) \\
\hline KU230195 & Ototyphlonemertes duplex & Ototyphlonemertes (duplex) duplex & Leasi et al. (2016) \\
\hline KU230194 & Ototyphlonemertes duplex & Ototyphlonemertes (duplex) duplex & Leasi et al. (2016) \\
\hline KU230193 & Ototyphlonemertes duplex & Ototyphlonemertes (duplex) duplex & Leasi et al. (2016) \\
\hline KU230192 & Ototyphlonemertes duplex & Ototyphlonemertes (duplex) duplex & Leasi et al. (2016) \\
\hline KU230191 & Ototyphlonemertes duplex & Ototyphlonemertes (duplex) duplex & Leasi et al. (2016) \\
\hline KU230190 & Ototyphlonemertes duplex & Ototyphlonemertes (duplex) duplex & Leasi et al. (2016) \\
\hline KU230189 & Ototyphlonemertes duplex & Ototyphlonemertes (duplex) duplex & Leasi et al. (2016) \\
\hline KU230188 & Ototyphlonemertes duplex & Ototyphlonemertes (duplex) duplex & Leasi et al. (2016) \\
\hline KU230187 & Ototyphlonemertes duplex & Ototyphlonemertes (duplex) duplex & Leasi et al. (2016) \\
\hline KU230186 & Ototyphlonemertes duplex & Ototyphlonemertes (duplex) duplex & Leasi et al. (2016) \\
\hline KU230185 & Ototyphlonemertes duplex & Ototyphlonemertes (duplex) duplex & Leasi et al. (2016) \\
\hline KU230184 & Ototyphlonemertes duplex & Ototyphlonemertes (duplex) duplex & Leasi et al. (2016) \\
\hline KU230183 & Ototyphlonemertes duplex & Ototyphlonemertes (duplex) duplex & Leasi et al. (2016) \\
\hline HQ848613 & Ototyphlonemertes correae & Ototyphlonemertes (duplex) duplex & Andrade et al. (2012) \\
\hline LC310993 & Ototyphlonemertes envalli & Ototyphlonemertes (duplex) envalli & present study \\
\hline
\end{tabular}


Appendix Continued.

\begin{tabular}{|c|c|c|c|}
\hline $\begin{array}{l}\text { Accession } \\
\text { number }\end{array}$ & $\begin{array}{l}\text { Species name registered in } \\
\text { DDBJ/EMBL/GenBank }\end{array}$ & Species name used in this paper & Source \\
\hline LC310994 & Ototyphlonemertes envalli & Ototyphlonemertes (duplex) envalli & present study \\
\hline LC310995 & Ototyphlonemertes envalli & Ototyphlonemertes (duplex) envalli & present study \\
\hline LC310996 & Ototyphlonemertes envalli & Ototyphlonemertes (duplex) envalli & present study \\
\hline KU245363 & Ototyphlonemertes duplex & Ototyphlonemertes (duplex) evelinae & Leasi et al. (2016) \\
\hline KU230163 & Ototyphlonemertes duplex & Ototyphlonemertes (duplex) evelinae & Leasi et al. (2016) \\
\hline KU230162 & Ototyphlonemertes duplex & Ototyphlonemertes (duplex) evelinae & Leasi et al. (2016) \\
\hline KU230161 & Ototyphlonemertes duplex & Ototyphlonemertes (duplex) evelinae & Leasi et al. (2016) \\
\hline KU230160 & Ototyphlonemertes duplex & Ototyphlonemertes (duplex) evelinae & Leasi et al. (2016) \\
\hline KU230159 & Ototyphlonemertes duplex & Ototyphlonemertes (duplex) evelinae & Leasi et al. (2016) \\
\hline KU230158 & Ototyphlonemertes duplex & Ototyphlonemertes (duplex) evelinae & Leasi et al. (2016) \\
\hline KU230157 & Ototyphlonemertes duplex & Ototyphlonemertes (duplex) evelinae & Leasi et al. (2016) \\
\hline KU230156 & Ototyphlonemertes duplex & Ototyphlonemertes (duplex) evelinae & Leasi et al. (2016) \\
\hline KU230155 & Ototyphlonemertes duplex & Ototyphlonemertes (duplex) evelinae & Leasi et al. (2016) \\
\hline KU230154 & Ototyphlonemertes duplex & Ototyphlonemertes (duplex) evelinae & Leasi et al. (2016) \\
\hline KU230153 & Ototyphlonemertes duplex & Ototyphlonemertes (duplex) evelinae & Leasi et al. (2016) \\
\hline KU230152 & Ototyphlonemertes duplex & Ototyphlonemertes (duplex) evelinae & Leasi et al. (2016) \\
\hline KU230151 & Ototyphlonemertes duplex & Ototyphlonemertes (duplex) evelinae & Leasi et al. (2016) \\
\hline KU230150 & Ototyphlonemertes evelinae & Ototyphlonemertes (duplex) evelinae & Leasi et al. (2016) \\
\hline KU230149 & Ototyphlonemertes evelinae & Ototyphlonemertes (duplex) evelinae & Leasi et al. (2016) \\
\hline KU230148 & Ototyphlonemertes evelinae & Ototyphlonemertes (duplex) evelinae & Leasi et al. (2016) \\
\hline KU230147 & Ototyphlonemertes evelinae & Ototyphlonemertes (duplex) evelinae & Leasi et al. (2016) \\
\hline KU230146 & Ototyphlonemertes duplex & Ototyphlonemertes (duplex) evelinae & Leasi et al. (2016) \\
\hline KU230145 & Ototyphlonemertes duplex & Ototyphlonemertes (duplex) evelinae & Leasi et al. (2016) \\
\hline KU230144 & Ototyphlonemertes duplex & Ototyphlonemertes (duplex) evelinae & Leasi et al. (2016) \\
\hline KU230143 & Ototyphlonemertes duplex & Ototyphlonemertes (duplex) evelinae & Leasi et al. (2016) \\
\hline KU230142 & Ototyphlonemertes evelinae & Ototyphlonemertes (duplex) evelinae & Leasi et al. (2016) \\
\hline KU230141 & Ototyphlonemertes duplex & Ototyphlonemertes (duplex) evelinae & Leasi et al. (2016) \\
\hline KU230140 & Ototyphlonemertes duplex & Ototyphlonemertes (duplex) evelinae & Leasi et al. (2016) \\
\hline KU230139 & Ototyphlonemertes duplex & Ototyphlonemertes (duplex) evelinae & Leasi et al. (2016) \\
\hline KU230138 & Ototyphlonemertes duplex & Ototyphlonemertes (duplex) evelinae & Leasi et al. (2016) \\
\hline KU230137 & Ototyphlonemertes duplex & Ototyphlonemertes (duplex) evelinae & Leasi et al. (2016) \\
\hline KU230136 & Ototyphlonemertes duplex & Ototyphlonemertes (duplex) evelinae & Leasi et al. (2016) \\
\hline KU230135 & Ototyphlonemertes duplex & Ototyphlonemertes (duplex) evelinae & Leasi et al. (2016) \\
\hline KU230134 & Ototyphlonemertes duplex & Ototyphlonemertes (duplex) evelinae & Leasi et al. (2016) \\
\hline KU230133 & Ototyphlonemertes duplex & Ototyphlonemertes (duplex) evelinae & Leasi et al. (2016) \\
\hline KU230132 & Ototyphlonemertes duplex & Ototyphlonemertes (duplex) evelinae & Leasi et al. (2016) \\
\hline KM083889 & Ototyphlonemertes duplex & Ototyphlonemertes (duplex) evelinae & Leasi and Norenburg (2014) \\
\hline KM083885 & Ototyphlonemertes duplex & Ototyphlonemertes (duplex) evelinae & Leasi and Norenburg (2014) \\
\hline KM083878 & Ototyphlonemertes duplex & Ototyphlonemertes (duplex) evelinae & Leasi and Norenburg (2014) \\
\hline KM083857 & Ototyphlonemertes duplex & Ototyphlonemertes (duplex) evelinae & Leasi and Norenburg (2014) \\
\hline KM083856 & Ototyphlonemertes duplex & Ototyphlonemertes (duplex) evelinae & Leasi and Norenburg (2014) \\
\hline KM083855 & Ototyphlonemertes duplex & Ototyphlonemertes (duplex) evelinae & Leasi and Norenburg (2014) \\
\hline KM083850 & Ototyphlonemertes duplex & Ototyphlonemertes (duplex) evelinae & Leasi and Norenburg (2014) \\
\hline KM083847 & Ototyphlonemertes duplex & Ototyphlonemertes (duplex) evelinae & Leasi and Norenburg (2014) \\
\hline KM094175 & Ototyphlonemertes duplex & Ototyphlonemertes (duplex) evelinae & Leasi and Norenburg (2014) \\
\hline LC310997 & Ototyphlonemertes norenburgi & Ototyphlonemertes (duplex) norenburgi & present study \\
\hline LC310998 & Ototyphlonemertes norenburgi & Ototyphlonemertes (duplex) norenburgi & present study \\
\hline KU230182 & Ototyphlonemertes duplex & Ototyphlonemertes (duplex) sp. 1 & Leasi et al. (2016) \\
\hline KU230181 & Ototyphlonemertes duplex & Ototyphlonemertes (duplex) sp. 1 & Leasi et al. (2016) \\
\hline KU230180 & Ototyphlonemertes duplex & Ototyphlonemertes (duplex) sp. 1 & Leasi et al. (2016) \\
\hline KU230179 & Ototyphlonemertes duplex & Ototyphlonemertes (duplex) sp. 1 & Leasi et al. (2016) \\
\hline KU230178 & Ototyphlonemertes duplex & Ototyphlonemertes (duplex) sp. 1 & Leasi et al. (2016) \\
\hline KU230177 & Ototyphlonemertes duplex & Ototyphlonemertes (duplex) sp. 1 & Leasi et al. (2016) \\
\hline KU230176 & Ototyphlonemertes duplex & Ototyphlonemertes (duplex) sp. 1 & Leasi et al. (2016) \\
\hline KU230175 & Ototyphlonemertes duplex & Ototyphlonemertes (duplex) sp. 1 & Leasi et al. (2016) \\
\hline KU230174 & Ototyphlonemertes duplex & Ototyphlonemertes (duplex) sp. 1 & Leasi et al. (2016) \\
\hline KU230173 & Ototyphlonemertes duplex & Ototyphlonemertes (duplex) sp. 1 & Leasi et al. (2016) \\
\hline KU230172 & Ototyphlonemertes duplex & Ototyphlonemertes (duplex) sp. 1 & Leasi et al. (2016) \\
\hline KU230171 & Ototyphlonemertes duplex & Ototyphlonemertes (duplex) sp. 1 & Leasi et al. (2016) \\
\hline KU230170 & Ototyphlonemertes duplex & Ototyphlonemertes (duplex) sp. 1 & Leasi et al. (2016) \\
\hline KU230169 & Ototyphlonemertes duplex & Ototyphlonemertes (duplex) sp. 1 & Leasi et al. (2016) \\
\hline
\end{tabular}


Appendix Continued.

\begin{tabular}{|c|c|c|c|}
\hline $\begin{array}{l}\text { Accession } \\
\text { number }\end{array}$ & $\begin{array}{l}\text { Species name registered in } \\
\text { DDBJ/EMBL/GenBank }\end{array}$ & Species name used in this paper & Source \\
\hline KU230168 & Ototyphlonemertes duplex & Ototyphlonemertes (duplex) sp. 1 & Leasi et al. (2016) \\
\hline KU230167 & Ototyphlonemertes duplex & Ototyphlonemertes (duplex) sp. 1 & Leasi et al. (2016) \\
\hline KU230166 & Ototyphlonemertes duplex & Ototyphlonemertes (duplex) sp. 1 & Leasi et al. (2016) \\
\hline KU230165 & Ototyphlonemertes duplex & Ototyphlonemertes (duplex) sp. 1 & Leasi et al. (2016) \\
\hline KU230164 & Ototyphlonemertes duplex & Ototyphlonemertes (duplex) sp. 1 & Leasi et al. (2016) \\
\hline KU230233 & Ototyphlonemertes duplex & Ototyphlonemertes (duplex) sp. 2 & Leasi et al. (2016) \\
\hline KU230232 & Ototyphlonemertes duplex & Ototyphlonemertes (duplex) sp. 2 & Leasi et al. (2016) \\
\hline KU230231 & Ototyphlonemertes duplex & Ototyphlonemertes (duplex) sp. 2 & Leasi et al. (2016) \\
\hline KU230244 & Ototyphlonemertes duplex & Ototyphlonemertes (duplex) sp. 4 & Leasi et al. (2016) \\
\hline KU230243 & Ototyphlonemertes duplex & Ototyphlonemertes (duplex) sp. 4 & Leasi et al. (2016) \\
\hline KU230242 & Ototyphlonemertes duplex & Ototyphlonemertes (duplex) sp. 4 & Leasi et al. (2016) \\
\hline KU230241 & Ototyphlonemertes duplex & Ototyphlonemertes (duplex) sp. 4 & Leasi et al. (2016) \\
\hline KU230240 & Ototyphlonemertes duplex & Ototyphlonemertes (duplex) sp. 5 & Leasi et al. (2016) \\
\hline KU230239 & Ototyphlonemertes duplex & Ototyphlonemertes (duplex) sp. 5 & Leasi et al. (2016) \\
\hline KU230238 & Ototyphlonemertes duplex & Ototyphlonemertes (duplex) sp. 5 & Leasi et al. (2016) \\
\hline KU230237 & Ototyphlonemertes duplex & Ototyphlonemertes (duplex) sp. 5 & Leasi et al. (2016) \\
\hline KU230236 & Ototyphlonemertes duplex & Ototyphlonemertes (duplex) sp. 5 & Leasi et al. (2016) \\
\hline KU230235 & Ototyphlonemertes duplex & Ototyphlonemertes (duplex) sp. 5 & Leasi et al. (2016) \\
\hline KU230234 & Ototyphlonemertes duplex & Ototyphlonemertes (duplex) sp. 5 & Leasi et al. (2016) \\
\hline KM083834 & Ototyphlonemertes duplex & Ototyphlonemertes (duplex) sp. 5 & Leasi and Norenburg (2014) \\
\hline KM083833 & Ototyphlonemertes duplex & Ototyphlonemertes (duplex) sp. 5 & Leasi and Norenburg (2014) \\
\hline KM083832 & Ototyphlonemertes duplex & Ototyphlonemertes (duplex) sp. 5 & Leasi and Norenburg (2014) \\
\hline KM083831 & Ototyphlonemertes duplex & Ototyphlonemertes (duplex) sp. 5 & Leasi and Norenburg (2014) \\
\hline KM083829 & Ototyphlonemertes duplex & Ototyphlonemertes (duplex) sp. 5 & Leasi and Norenburg (2014) \\
\hline KM083827 & Ototyphlonemertes duplex & Ototyphlonemertes (duplex) sp. 5 & Leasi and Norenburg (2014) \\
\hline KM083824 & Ototyphlonemertes duplex & Ototyphlonemertes (duplex) sp. 5 & Leasi and Norenburg (2014) \\
\hline KM083823 & Ototyphlonemertes duplex & Ototyphlonemertes (duplex) sp. 5 & Leasi and Norenburg (2014) \\
\hline KU230131 & Ototyphlonemertes lactea & Ototyphlonemertes (macintoshi) ani & Leasi et al. (2016) \\
\hline KU230130 & Ototyphlonemertes lactea & Ototyphlonemertes (macintoshi) ani & Leasi et al. (2016) \\
\hline KU230129 & Ototyphlonemertes lactea & Ototyphlonemertes (macintoshi) ani & Leasi et al. (2016) \\
\hline LC310999 & Ototyphlonemertes ani & Ototyphlonemertes (macintoshi) ani & present study \\
\hline LC311000 & Ototyphlonemertes ani & Ototyphlonemertes (macintoshi) ani & present study \\
\hline LC311001 & Ototyphlonemertes ani & Ototyphlonemertes (macintoshi) ani & present study \\
\hline LC311002 & Ototyphlonemertes ani & Ototyphlonemertes (macintoshi) ani & present study \\
\hline LC311003 & Ototyphlonemertes ani & Ototyphlonemertes (macintoshi) ani & present study \\
\hline LC311004 & Ototyphlonemertes ani & Ototyphlonemertes (macintoshi) ani & present study \\
\hline LC311005 & Ototyphlonemertes ani & Ototyphlonemertes (macintoshi) ani & present study \\
\hline LC311006 & Ototyphlonemertes ani & Ototyphlonemertes (macintoshi) ani & present study \\
\hline KU230288 & Ototyphlonemertes macintoshi & Ototyphlonemertes (macintoshi) sp. 23 & Leasi et al. (2016) \\
\hline KM083842 & Ototyphlonemertes macintoshi & Ototyphlonemertes (macintoshi) sp. 23 & Leasi and Norenburg (2014) \\
\hline KU230289 & Ototyphlonemertes macintoshi & Ototyphlonemertes (macintoshi) sp. 24 & Leasi et al. (2016) \\
\hline KM083877 & Ototyphlonemertes macintoshi & Ototyphlonemertes (macintoshi) sp. 24 & Leasi and Norenburg (2014) \\
\hline KU230122 & Ototyphlonemertes lactea & Ototyphlonemertes (macintoshi) sp. 25 & Leasi et al. (2016) \\
\hline KU230121 & Ototyphlonemertes lactea & Ototyphlonemertes (macintoshi) sp. 25 & Leasi et al. (2016) \\
\hline KU230120 & Ototyphlonemertes lactea & Ototyphlonemertes (macintoshi) sp. 25 & Leasi et al. (2016) \\
\hline KU230119 & Ototyphlonemertes lactea & Ototyphlonemertes (macintoshi) sp. 25 & Leasi et al. (2016) \\
\hline KU230118 & Ototyphlonemertes lactea & Ototyphlonemertes (macintoshi) sp. 25 & Leasi et al. (2016) \\
\hline KU230117 & Ototyphlonemertes americana & Ototyphlonemertes (macintoshi) sp. 25 & Leasi et al. (2016) \\
\hline KU230116 & Ototyphlonemertes lactea & Ototyphlonemertes (macintoshi) sp. 25 & Leasi et al. (2016) \\
\hline KU230115 & Ototyphlonemertes lactea & Ototyphlonemertes (macintoshi) sp. 25 & Leasi et al. (2016) \\
\hline KU230114 & Ototyphlonemertes lactea & Ototyphlonemertes (macintoshi) sp. 25 & Leasi et al. (2016) \\
\hline KU230113 & Ototyphlonemertes lactea & Ototyphlonemertes (macintoshi) sp. 25 & Leasi et al. (2016) \\
\hline KU230112 & Ototyphlonemertes lactea & Ototyphlonemertes (macintoshi) sp. 25 & Leasi et al. (2016) \\
\hline KU230111 & Ototyphlonemertes lactea & Ototyphlonemertes (macintoshi) sp. 25 & Leasi et al. (2016) \\
\hline KU230110 & Ototyphlonemertes lactea & Ototyphlonemertes (macintoshi) sp. 25 & Leasi et al. (2016) \\
\hline KU230109 & Ototyphlonemertes lactea & Ototyphlonemertes (macintoshi) sp. 25 & Leasi et al. (2016) \\
\hline KU230108 & Ototyphlonemertes lactea & Ototyphlonemertes (macintoshi) sp. 25 & Leasi et al. (2016) \\
\hline KU230107 & Ototyphlonemertes americana & Ototyphlonemertes (macintoshi) sp. 25 & Leasi et al. (2016) \\
\hline KU245364 & Ototyphlonemertes lactea & Ototyphlonemertes (macintoshi) sp. 26 & Leasi et al. (2016) \\
\hline KU230106 & Ototyphlonemertes lactea & Ototyphlonemertes (macintoshi) sp. 26 & Leasi et al. (2016) \\
\hline KU230105 & Ototyphlonemertes lactea & Ototyphlonemertes (macintoshi) sp. 26 & Leasi et al. (2016) \\
\hline
\end{tabular}


Appendix Continued.

\begin{tabular}{|c|c|c|c|}
\hline $\begin{array}{l}\text { Accession } \\
\text { number }\end{array}$ & $\begin{array}{l}\text { Species name registered in } \\
\text { DDBJ/EMBL/GenBank }\end{array}$ & Species name used in this paper & Source \\
\hline KU230104 & Ototyphlonemertes lactea & Ototyphlonemertes (macintoshi) sp. 26 & Leasi et al. (2016) \\
\hline KU230103 & Ototyphlonemertes lactea & Ototyphlonemertes (macintoshi) sp. 26 & Leasi et al. (2016) \\
\hline KU230102 & Ototyphlonemertes lactea & Ototyphlonemertes (macintoshi) sp. 26 & Leasi et al. (2016) \\
\hline KU230101 & Ototyphlonemertes lactea & Ototyphlonemertes (macintoshi) sp. 26 & Leasi et al. (2016) \\
\hline KU230100 & Ototyphlonemertes lactea & Ototyphlonemertes (macintoshi) sp. 26 & Leasi et al. (2016) \\
\hline KU230099 & Ototyphlonemertes lactea & Ototyphlonemertes (macintoshi) sp. 26 & Leasi et al. (2016) \\
\hline KU230098 & Ototyphlonemertes lactea & Ototyphlonemertes (macintoshi) sp. 26 & Leasi et al. (2016) \\
\hline KU230097 & Ototyphlonemertes lactea & Ototyphlonemertes (macintoshi) sp. 26 & Leasi et al. (2016) \\
\hline KU230096 & Ototyphlonemertes lactea & Ototyphlonemertes (macintoshi) sp. 26 & Leasi et al. (2016) \\
\hline KU230095 & Ototyphlonemertes lactea & Ototyphlonemertes (macintoshi) sp. 26 & Leasi et al. (2016) \\
\hline KU230094 & Ototyphlonemertes lactea & Ototyphlonemertes (macintoshi) sp. 26 & Leasi et al. (2016) \\
\hline KU230093 & Ototyphlonemertes lactea & Ototyphlonemertes (macintoshi) sp. 26 & Leasi et al. (2016) \\
\hline KU230092 & Ototyphlonemertes lactea & Ototyphlonemertes (macintoshi) sp. 26 & Leasi et al. (2016) \\
\hline KU230091 & Ototyphlonemertes lactea & Ototyphlonemertes (macintoshi) sp. 26 & Leasi et al. (2016) \\
\hline KU230090 & Ototyphlonemertes lactea & Ototyphlonemertes (macintoshi) sp. 26 & Leasi et al. (2016) \\
\hline KU230089 & Ototyphlonemertes lactea & Ototyphlonemertes (macintoshi) sp. 26 & Leasi et al. (2016) \\
\hline KU230088 & Ototyphlonemertes lactea & Ototyphlonemertes (macintoshi) sp. 26 & Leasi et al. (2016) \\
\hline KU230087 & Ototyphlonemertes lactea & Ototyphlonemertes (macintoshi) sp. 26 & Leasi et al. (2016) \\
\hline KU230086 & Ototyphlonemertes lactea & Ototyphlonemertes (macintoshi) sp. 26 & Leasi et al. (2016) \\
\hline KU230085 & Ototyphlonemertes lactea & Ototyphlonemertes (macintoshi) sp. 26 & Leasi et al. (2016) \\
\hline KU230084 & Ototyphlonemertes lactea & Ototyphlonemertes (macintoshi) sp. 26 & Leasi et al. (2016) \\
\hline KU230083 & Ototyphlonemertes lactea & Ototyphlonemertes (macintoshi) sp. 26 & Leasi et al. (2016) \\
\hline KU230082 & Ototyphlonemertes lactea & Ototyphlonemertes (macintoshi) sp. 26 & Leasi et al. (2016) \\
\hline KU230081 & Ototyphlonemertes lactea & Ototyphlonemertes (macintoshi) sp. 26 & Leasi et al. (2016) \\
\hline KU230080 & Ototyphlonemertes lactea & Ototyphlonemertes (macintoshi) sp. 26 & Leasi et al. (2016) \\
\hline KU230079 & Ototyphlonemertes lactea & Ototyphlonemertes (macintoshi) sp. 26 & Leasi et al. (2016) \\
\hline KU230078 & Ototyphlonemertes lactea & Ototyphlonemertes (macintoshi) sp. 26 & Leasi et al. (2016) \\
\hline KU230077 & Ototyphlonemertes lactea & Ototyphlonemertes (macintoshi) sp. 26 & Leasi et al. (2016) \\
\hline KU230076 & Ototyphlonemertes lactea & Ototyphlonemertes (macintoshi) sp. 26 & Leasi et al. (2016) \\
\hline KU230075 & Ototyphlonemertes lactea & Ototyphlonemertes (macintoshi) sp. 26 & Leasi et al. (2016) \\
\hline KM083888 & Ototyphlonemertes lactea & Ototyphlonemertes (macintoshi) sp. 26 & Leasi and Norenburg (2014) \\
\hline KM083874 & Ototyphlonemertes lactea & Ototyphlonemertes (macintoshi) sp. 26 & Leasi and Norenburg (2014) \\
\hline KM083864 & Ototyphlonemertes lactea & Ototyphlonemertes (macintoshi) sp. 26 & Leasi and Norenburg (2014) \\
\hline KM083863 & Ototyphlonemertes lactea & Ototyphlonemertes (macintoshi) sp. 26 & Leasi and Norenburg (2014) \\
\hline KM083852 & Ototyphlonemertes lactea & Ototyphlonemertes (macintoshi) sp. 26 & Leasi and Norenburg (2014) \\
\hline KM083840 & Ototyphlonemertes lactea & Ototyphlonemertes (macintoshi) sp. 26 & Leasi and Norenburg (2014) \\
\hline KM083836 & Ototyphlonemertes lactea & Ototyphlonemertes (macintoshi) sp. 26 & Leasi and Norenburg (2014) \\
\hline KM083826 & Ototyphlonemertes lactea & Ototyphlonemertes (macintoshi) sp. 26 & Leasi and Norenburg (2014) \\
\hline KU230261 & Ototyphlonemertes macintoshi & Ototyphlonemertes (macintoshi) sp. 27 & Leasi et al. (2016) \\
\hline KU230260 & Ototyphlonemertes macintoshi & Ototyphlonemertes (macintoshi) sp. 27 & Leasi et al. (2016) \\
\hline KU230259 & Ototyphlonemertes macintoshi & Ototyphlonemertes (macintoshi) sp. 27 & Leasi et al. (2016) \\
\hline KU230258 & Ototyphlonemertes macintoshi & Ototyphlonemertes (macintoshi) sp. 27 & Leasi et al. (2016) \\
\hline KU230257 & Ototyphlonemertes macintoshi & Ototyphlonemertes (macintoshi) sp. 27 & Leasi et al. (2016) \\
\hline KU230256 & Ototyphlonemertes macintoshi & Ototyphlonemertes (macintoshi) sp. 27 & Leasi et al. (2016) \\
\hline KU230255 & Ototyphlonemertes macintoshi & Ototyphlonemertes (macintoshi) sp. 28 & Leasi et al. (2016) \\
\hline KU230254 & Ototyphlonemertes macintoshi & Ototyphlonemertes (macintoshi) sp. 28 & Leasi et al. (2016) \\
\hline KU230253 & Ototyphlonemertes macintoshi & Ototyphlonemertes (macintoshi) sp. 28 & Leasi et al. (2016) \\
\hline KU230252 & Ototyphlonemertes macintoshi & Ototyphlonemertes (macintoshi) sp. 28 & Leasi et al. (2016) \\
\hline KU230251 & Ototyphlonemertes macintoshi & Ototyphlonemertes (macintoshi) sp. 28 & Leasi et al. (2016) \\
\hline KU230250 & Ototyphlonemertes macintoshi & Ototyphlonemertes (macintoshi) sp. 28 & Leasi et al. (2016) \\
\hline KU230249 & Ototyphlonemertes macintoshi & Ototyphlonemertes (macintoshi) sp. 28 & Leasi et al. (2016) \\
\hline KU230248 & Ototyphlonemertes macintoshi & Ototyphlonemertes (macintoshi) sp. 28 & Leasi et al. (2016) \\
\hline KU230247 & Ototyphlonemertes macintoshi & Ototyphlonemertes (macintoshi) sp. 28 & Leasi et al. (2016) \\
\hline KU230246 & Ototyphlonemertes macintoshi & Ototyphlonemertes (macintoshi) sp. 28 & Leasi et al. (2016) \\
\hline KU230245 & Ototyphlonemertes macintoshi & Ototyphlonemertes (macintoshi) sp. 28 & Leasi et al. (2016) \\
\hline HQ848605 & Ototyphlonemertes macintoshi & Ototyphlonemertes (macintoshi) sp. 28 & Andrade et al. (2012) \\
\hline KF935545 & Cf. Ototyphlonemertes pallida sp. & Ototyphlonemertes (macintoshi) sp. 28 & Kvist et al. (2014) \\
\hline KU230074 & Ototyphlonemertes lactea & Ototyphlonemertes (macintoshi) sp. 29 & Leasi et al. (2016) \\
\hline KU230073 & Ototyphlonemertes lactea & Ototyphlonemertes (macintoshi) sp. 29 & Leasi et al. (2016) \\
\hline KU230072 & Ototyphlonemertes lactea & Ototyphlonemertes (macintoshi) sp. 29 & Leasi et al. (2016) \\
\hline KU230071 & Ototyphlonemertes lactea & Ototyphlonemertes (macintoshi) sp. 29 & Leasi et al. (2016) \\
\hline
\end{tabular}


Appendix Continued.

\begin{tabular}{|c|c|c|c|}
\hline $\begin{array}{l}\text { Accession } \\
\text { number }\end{array}$ & $\begin{array}{l}\text { Species name registered in } \\
\text { DDBJ/EMBL/GenBank }\end{array}$ & Species name used in this paper & Source \\
\hline KU230070 & Ototyphlonemertes lactea & Ototyphlonemertes (macintoshi) sp. 29 & Leasi et al. (2016) \\
\hline KU230069 & Ototyphlonemertes lactea & Ototyphlonemertes (macintoshi) sp. 29 & Leasi et al. (2016) \\
\hline KU230286 & Ototyphlonemertes macintoshi & Ototyphlonemertes (macintoshi) sp. 30 & Leasi et al. (2016) \\
\hline KU230285 & Ototyphlonemertes macintoshi & Ototyphlonemertes (macintoshi) sp. 30 & Leasi et al. (2016) \\
\hline KU230284 & Ototyphlonemertes macintoshi & Ototyphlonemertes (macintoshi) sp. 30 & Leasi et al. (2016) \\
\hline KU230283 & Ototyphlonemertes macintoshi & Ototyphlonemertes (macintoshi) sp. 30 & Leasi et al. (2016) \\
\hline KU230282 & Ototyphlonemertes macintoshi & Ototyphlonemertes (macintoshi) sp. 30 & Leasi et al. (2016) \\
\hline KU230281 & Ototyphlonemertes macintoshi & Ototyphlonemertes (macintoshi) sp. 30 & Leasi et al. (2016) \\
\hline KU230280 & Ototyphlonemertes macintoshi & Ototyphlonemertes (macintoshi) sp. 30 & Leasi et al. (2016) \\
\hline KU230279 & Ototyphlonemertes macintoshi & Ototyphlonemertes (macintoshi) sp. 30 & Leasi et al. (2016) \\
\hline KU230278 & Ototyphlonemertes macintoshi & Ototyphlonemertes (macintoshi) sp. 30 & Leasi et al. (2016) \\
\hline KU230277 & Ototyphlonemertes macintoshi & Ototyphlonemertes (macintoshi) sp. 30 & Leasi et al. (2016) \\
\hline KU230276 & Ototyphlonemertes macintoshi & Ototyphlonemertes (macintoshi) sp. 30 & Leasi et al. (2016) \\
\hline KU230275 & Ototyphlonemertes macintoshi & Ototyphlonemertes (macintoshi) sp. 30 & Leasi et al. (2016) \\
\hline KU230274 & Ototyphlonemertes macintoshi & Ototyphlonemertes (macintoshi) sp. 30 & Leasi et al. (2016) \\
\hline KU230273 & Ototyphlonemertes macintoshi & Ototyphlonemertes (macintoshi) sp. 30 & Leasi et al. (2016) \\
\hline KU230272 & Ototyphlonemertes macintoshi & Ototyphlonemertes (macintoshi) sp. 30 & Leasi et al. (2016) \\
\hline KU230271 & Ototyphlonemertes macintoshi & Ototyphlonemertes (macintoshi) sp. 30 & Leasi et al. (2016) \\
\hline KU230270 & Ototyphlonemertes macintoshi & Ototyphlonemertes (macintoshi) sp. 30 & Leasi et al. (2016) \\
\hline KU230269 & Ototyphlonemertes macintoshi & Ototyphlonemertes (macintoshi) sp. 30 & Leasi et al. (2016) \\
\hline KU230268 & Ototyphlonemertes macintoshi & Ototyphlonemertes (macintoshi) sp. 30 & Leasi et al. (2016) \\
\hline KU230267 & Ototyphlonemertes macintoshi & Ototyphlonemertes (macintoshi) sp. 30 & Leasi et al. (2016) \\
\hline KU230266 & Ototyphlonemertes macintoshi & Ototyphlonemertes (macintoshi) sp. 30 & Leasi et al. (2016) \\
\hline KU230265 & Ototyphlonemertes macintoshi & Ototyphlonemertes (macintoshi) sp. 30 & Leasi et al. (2016) \\
\hline KU230264 & Ototyphlonemertes macintoshi & Ototyphlonemertes (macintoshi) sp. 30 & Leasi et al. (2016) \\
\hline KU230263 & Ototyphlonemertes macintoshi & Ototyphlonemertes (macintoshi) sp. 30 & Leasi et al. (2016) \\
\hline KU230262 & Ototyphlonemertes macintoshi & Ototyphlonemertes (macintoshi) sp. 30 & Leasi et al. (2016) \\
\hline KM083884 & Ototyphlonemertes macintoshi & Ototyphlonemertes (macintoshi) sp. 30 & Leasi and Norenburg (2014) \\
\hline KM083875 & Ototyphlonemertes macintoshi & Ototyphlonemertes (macintoshi) sp. 30 & Leasi and Norenburg (2014) \\
\hline KM083870 & Ototyphlonemertes macintoshi & Ototyphlonemertes (macintoshi) sp. 30 & Leasi and Norenburg (2014) \\
\hline KM083854 & Ototyphlonemertes macintoshi & Ototyphlonemertes (macintoshi) sp. 30 & Leasi and Norenburg (2014) \\
\hline KM083841 & Ototyphlonemertes macintoshi & Ototyphlonemertes (macintoshi) sp. 30 & Leasi and Norenburg (2014) \\
\hline KM083838 & Ototyphlonemertes macintoshi & Ototyphlonemertes (macintoshi) sp. 30 & Leasi and Norenburg (2014) \\
\hline KM083837 & Ototyphlonemertes macintoshi & Ototyphlonemertes (macintoshi) sp. 30 & Leasi and Norenburg (2014) \\
\hline KM083828 & Ototyphlonemertes macintoshi & Ototyphlonemertes (macintoshi) sp. 30 & Leasi and Norenburg (2014) \\
\hline KU230128 & Ototyphlonemertes lactea & Ototyphlonemertes (macintoshi) sp. 31 & Leasi et al. (2016) \\
\hline KU230127 & Ototyphlonemertes lactea & Ototyphlonemertes (macintoshi) sp. 31 & Leasi et al. (2016) \\
\hline KU230126 & Ototyphlonemertes lactea & Ototyphlonemertes (macintoshi) sp. 31 & Leasi et al. (2016) \\
\hline KU230125 & Ototyphlonemertes lactea & Ototyphlonemertes (macintoshi) sp. 32 & Leasi et al. (2016) \\
\hline KU230124 & Ototyphlonemertes lactea & Ototyphlonemertes (macintoshi) sp. 32 & Leasi et al. (2016) \\
\hline KU230123 & Ototyphlonemertes lactea & Ototyphlonemertes (macintoshi) sp. 32 & Leasi et al. (2016) \\
\hline KU230291 & Ototyphlonemertes macintoshi & Ototyphlonemertes (macintoshi) sp. 33 & Leasi et al. (2016) \\
\hline KU230290 & Ototyphlonemertes macintoshi & Ototyphlonemertes (macintoshi) sp. 33 & Leasi et al. (2016) \\
\hline KU230044 & Ototyphlonemertes americana & Ototyphlonemertes (macintoshi) sp. 34 & Leasi et al. (2016) \\
\hline KU230043 & Ototyphlonemertes lactea & Ototyphlonemertes (macintoshi) sp. 34 & Leasi et al. (2016) \\
\hline KU230042 & Ototyphlonemertes lactea & Ototyphlonemertes (macintoshi) sp. 34 & Leasi et al. (2016) \\
\hline KU230041 & Ototyphlonemertes lactea & Ototyphlonemertes (macintoshi) sp. 34 & Leasi et al. (2016) \\
\hline KU230040 & Ototyphlonemertes lactea & Ototyphlonemertes (macintoshi) sp. 34 & Leasi et al. (2016) \\
\hline KU230039 & Ototyphlonemertes lactea & Ototyphlonemertes (macintoshi) sp. 34 & Leasi et al. (2016) \\
\hline KU230038 & Ototyphlonemertes lactea & Ototyphlonemertes (macintoshi) sp. 34 & Leasi et al. (2016) \\
\hline KU230037 & Ototyphlonemertes lactea & Ototyphlonemertes (macintoshi) sp. 34 & Leasi et al. (2016) \\
\hline KU230036 & Ototyphlonemertes lactea & Ototyphlonemertes (macintoshi) sp. 34 & Leasi et al. (2016) \\
\hline KU230035 & Ototyphlonemertes lactea & Ototyphlonemertes (macintoshi) sp. 34 & Leasi et al. (2016) \\
\hline KU230034 & Ototyphlonemertes lactea & Ototyphlonemertes (macintoshi) sp. 34 & Leasi et al. (2016) \\
\hline KU230033 & Ototyphlonemertes lactea & Ototyphlonemertes (macintoshi) sp. 34 & Leasi et al. (2016) \\
\hline KU230032 & Ototyphlonemertes lactea & Ototyphlonemertes (macintoshi) sp. 34 & Leasi et al. (2016) \\
\hline KU230031 & Ototyphlonemertes lactea & Ototyphlonemertes (macintoshi) sp. 34 & Leasi et al. (2016) \\
\hline KU230068 & Ototyphlonemertes lactea & Ototyphlonemertes (macintoshi) sp. 35 & Leasi et al. (2016) \\
\hline KU230067 & Ototyphlonemertes lactea & Ototyphlonemertes (macintoshi) sp. 35 & Leasi et al. (2016) \\
\hline KU230066 & Ototyphlonemertes lactea & Ototyphlonemertes (macintoshi) sp. 35 & Leasi et al. (2016) \\
\hline KU230065 & Ototyphlonemertes lactea & Ototyphlonemertes (macintoshi) sp. 35 & Leasi et al. (2016) \\
\hline
\end{tabular}


Appendix Continued.

\begin{tabular}{|c|c|c|c|}
\hline $\begin{array}{l}\text { Accession } \\
\text { number }\end{array}$ & $\begin{array}{l}\text { Species name registered in } \\
\text { DDBJ/EMBL/GenBank }\end{array}$ & Species name used in this paper & Source \\
\hline KU230064 & Ototyphlonemertes lactea & Ototyphlonemertes (macintoshi) sp. 35 & Leasi et al. (2016) \\
\hline KU230063 & Ototyphlonemertes lactea & Ototyphlonemertes (macintoshi) sp. 35 & Leasi et al. (2016) \\
\hline KU230062 & Ototyphlonemertes lactea & Ototyphlonemertes (macintoshi) sp. 35 & Leasi et al. (2016) \\
\hline KU230061 & Ototyphlonemertes lactea & Ototyphlonemertes (macintoshi) sp. 35 & Leasi et al. (2016) \\
\hline KU230060 & Ototyphlonemertes lactea & Ototyphlonemertes (macintoshi) sp. 35 & Leasi et al. (2016) \\
\hline KU230059 & Ototyphlonemertes lactea & Ototyphlonemertes (macintoshi) sp. 35 & Leasi et al. (2016) \\
\hline KU230058 & Ototyphlonemertes lactea & Ototyphlonemertes (macintoshi) sp. 35 & Leasi et al. (2016) \\
\hline KU230057 & Ototyphlonemertes lactea & Ototyphlonemertes (macintoshi) sp. 35 & Leasi et al. (2016) \\
\hline KU230056 & Ototyphlonemertes lactea & Ototyphlonemertes (macintoshi) sp. 35 & Leasi et al. (2016) \\
\hline KU230055 & Ototyphlonemertes lactea & Ototyphlonemertes (macintoshi) sp. 35 & Leasi et al. (2016) \\
\hline KU230054 & Ototyphlonemertes lactea & Ototyphlonemertes (macintoshi) sp. 35 & Leasi et al. (2016) \\
\hline KU230053 & Ototyphlonemertes lactea & Ototyphlonemertes (macintoshi) sp. 35 & Leasi et al. (2016) \\
\hline KU230052 & Ototyphlonemertes lactea & Ototyphlonemertes (macintoshi) sp. 35 & Leasi et al. (2016) \\
\hline KU230051 & Ototyphlonemertes lactea & Ototyphlonemertes (macintoshi) sp. 35 & Leasi et al. (2016) \\
\hline KU230050 & Ototyphlonemertes lactea & Ototyphlonemertes (macintoshi) sp. 35 & Leasi et al. (2016) \\
\hline KU230049 & Ototyphlonemertes lactea & Ototyphlonemertes (macintoshi) sp. 35 & Leasi et al. (2016) \\
\hline KU230048 & Ototyphlonemertes lactea & Ototyphlonemertes (macintoshi) sp. 35 & Leasi et al. (2016) \\
\hline KU230047 & Ototyphlonemertes lactea & Ototyphlonemertes (macintoshi) sp. 35 & Leasi et al. (2016) \\
\hline KU230046 & Ototyphlonemertes lactea & Ototyphlonemertes (macintoshi) sp. 35 & Leasi et al. (2016) \\
\hline KU230045 & Ototyphlonemertes lactea & Ototyphlonemertes (macintoshi) sp. 35 & Leasi et al. (2016) \\
\hline KU230287 & Ototyphlonemertes macintoshi & Ototyphlonemertes (macintoshi) sp. 36 & Leasi et al. (2016) \\
\hline KT736314 & Ototyphlonemertes pallida & Ototyphlonemertes (pallida) pallida & Leasi et al. (2016) \\
\hline KT736313 & Ototyphlonemertes pallida & Ototyphlonemertes (pallida) pallida & Leasi et al. (2016) \\
\hline KT736312 & Ototyphlonemertes pallida & Ototyphlonemertes (pallida) pallida & Leasi et al. (2016) \\
\hline KT736311 & Ototyphlonemertes pallida & Ototyphlonemertes (pallida) pallida & Leasi et al. (2016) \\
\hline KT736310 & Ototyphlonemertes pallida & Ototyphlonemertes (pallida) pallida & Leasi et al. (2016) \\
\hline KT736309 & Ototyphlonemertes pallida & Ototyphlonemertes (pallida) pallida & Leasi et al. (2016) \\
\hline KT736308 & Ototyphlonemertes pallida & Ototyphlonemertes (pallida) pallida & Leasi et al. (2016) \\
\hline KT736307 & Ototyphlonemertes pallida & Ototyphlonemertes (pallida) pallida & Leasi et al. (2016) \\
\hline KT736306 & Ototyphlonemertes pallida & Ototyphlonemertes (pallida) pallida & Leasi et al. (2016) \\
\hline KT736305 & Ototyphlonemertes pallida & Ototyphlonemertes (pallida) pallida & Leasi et al. (2016) \\
\hline KT736304 & Ototyphlonemertes pallida & Ototyphlonemertes (pallida) pallida & Leasi et al. (2016) \\
\hline KT736303 & Ototyphlonemertes pallida & Ototyphlonemertes (pallida) pallida & Leasi et al. (2016) \\
\hline KT730600 & Ototyphlonemertes santacruzensis & Ototyphlonemertes (pallida) sp. 10 cf. santacruzensis & Leasi et al. (2016) \\
\hline KT730599 & Ototyphlonemertes santacruzensis & Ototyphlonemertes (pallida) sp. 10 cf. santacruzensis & Leasi et al. (2016) \\
\hline KT730622 & Ototyphlonemertes santacruzensis & Ototyphlonemertes (pallida) sp. $11 \mathrm{cf}$ santacruzensis & Leasi et al. (2016) \\
\hline KT730621 & Ototyphlonemertes santacruzensis & Ototyphlonemertes (pallida) sp. $11 \mathrm{cf}$. santacruzensis & Leasi et al. (2016) \\
\hline KT730620 & Ototyphlonemertes santacruzensis & Ototyphlonemertes (pallida) sp. $11 \mathrm{cf}$ santacruzensis & Leasi et al. (2016) \\
\hline KT730619 & Ototyphlonemertes santacruzensis & Ototyphlonemertes (pallida) sp. $11 \mathrm{cf}$ santacruzensis & Leasi et al. (2016) \\
\hline KM083886 & Ototyphlonemertes santacruzensis & Ototyphlonemertes (pallida) sp. 11 cf. santacruzensis & Leasi and Norenburg (2014) \\
\hline KM083883 & Ototyphlonemertes santacruzensis & Ototyphlonemertes (pallida) sp. $11 \mathrm{cf}$. santacruzensis & Leasi and Norenburg (2014) \\
\hline KM083881 & Ototyphlonemertes santacruzensis & Ototyphlonemertes (pallida) sp. $11 \mathrm{cf}$. santacruzensis & Leasi and Norenburg (2014) \\
\hline KM083879 & Ototyphlonemertes santacruzensis & Ototyphlonemertes (pallida) sp. 11 cf. santacruzensis & Leasi and Norenburg (2014) \\
\hline KM083872 & Ototyphlonemertes santacruzensis & Ototyphlonemertes (pallida) sp. 11 cf. santacruzensis & Leasi and Norenburg (2014) \\
\hline KM083868 & Ototyphlonemertes santacruzensis & Ototyphlonemertes (pallida) sp. $11 \mathrm{cf}$. santacruzensis & Leasi and Norenburg (2014) \\
\hline KM083860 & Ototyphlonemertes santacruzensis & Ototyphlonemertes (pallida) sp. 11 cf. santacruzensis & Leasi and Norenburg (2014) \\
\hline KM083851 & Ototyphlonemertes santacruzensis & Ototyphlonemertes (pallida) sp. 11 cf. santacruzensis & Leasi and Norenburg (2014) \\
\hline KM083822 & Ototyphlonemertes santacruzensis & Ototyphlonemertes (pallida) sp. 11 cf. santacruzensis & Leasi and Norenburg (2014) \\
\hline KT730625 & Ototyphlonemertes santacruzensis & Ototyphlonemertes (pallida) sp. 12 cf. santacruzensis & Leasi et al. (2016) \\
\hline KT730624 & Ototyphlonemertes santacruzensis & Ototyphlonemertes (pallida) sp. 12 cf. santacruzensis & Leasi et al. (2016) \\
\hline KM083849 & Ototyphlonemertes santacruzensis & Ototyphlonemertes (pallida) sp. 12 cf. santacruzensis & Leasi and Norenburg (2014) \\
\hline KM083835 & Ototyphlonemertes santacruzensis & Ototyphlonemertes (pallida) sp. 12 cf. santacruzensis & Leasi and Norenburg (2014) \\
\hline KM083821 & Ototyphlonemertes santacruzensis & Ototyphlonemertes (pallida) sp. 12 cf. santacruzensis & Leasi and Norenburg (2014) \\
\hline KT722730 & Ototyphlonemertes erneba & Ototyphlonemertes (pallida) sp. 17 cf. erneba & Leasi et al. (2016) \\
\hline KT722729 & Ototyphlonemertes erneba & Ototyphlonemertes (pallida) sp. 17 cf. erneba & Leasi et al. (2016) \\
\hline KT722728 & Ototyphlonemertes erneba & Ototyphlonemertes (pallida) sp. $17 \mathrm{cf}$ erneba & Leasi et al. (2016) \\
\hline KT722721 & Ototyphlonemertes erneba & Ototyphlonemertes (pallida) sp. 19 cf. erneba & Leasi et al. (2016) \\
\hline KT722720 & Ototyphlonemertes erneba & Ototyphlonemertes (pallida) sp. 19 cf. erneba & Leasi et al. (2016) \\
\hline KT722719 & Ototyphlonemertes erneba & Ototyphlonemertes (pallida) sp. 19 cf. erneba & Leasi et al. (2016) \\
\hline KT722718 & Ototyphlonemertes erneba & Ototyphlonemertes (pallida) sp. 19 cf. erneba & Leasi et al. (2016) \\
\hline KT722717 & Ototyphlonemertes erneba & Ototyphlonemertes (pallida) sp. 19 cf. erneba & Leasi et al. (2016) \\
\hline
\end{tabular}


Appendix Continued.

\begin{tabular}{|c|c|c|c|}
\hline $\begin{array}{l}\text { Accession } \\
\text { number }\end{array}$ & $\begin{array}{l}\text { Species name registered in } \\
\text { DDBJ/EMBL/GenBank }\end{array}$ & Species name used in this paper & Source \\
\hline KT722716 & Ototyphlonemertes erneba & Ototyphlonemertes (pallida) sp. 19 cf. erneba & Leasi et al. (2016) \\
\hline KT722715 & Ototyphlonemertes erneba & Ototyphlonemertes (pallida) sp. 19 cf. erneba & Leasi et al. (2016) \\
\hline KT722714 & Ototyphlonemertes erneba & Ototyphlonemertes (pallida) sp. 19 cf. erneba & Leasi et al. (2016) \\
\hline KM083862 & Ototyphlonemertes erneba & Ototyphlonemertes (pallida) sp. 19 cf. erneba & Leasi and Norenburg (2014) \\
\hline KM083853 & Ototyphlonemertes erneba & Ototyphlonemertes (pallida) sp. 19 cf. erneba & Leasi and Norenburg (2014) \\
\hline KM083845 & Ototyphlonemertes erneba & Ototyphlonemertes (pallida) sp. 19 cf. erneba & Leasi and Norenburg (2014) \\
\hline KT722727 & Ototyphlonemertes erneba & Ototyphlonemertes (pallida) sp. 20 cf. erneba & Leasi et al. (2016) \\
\hline KT722726 & Ototyphlonemertes erneba & Ototyphlonemertes (pallida) sp. 20 cf. erneba & Leasi et al. (2016) \\
\hline KT722725 & Ototyphlonemertes erneba & Ototyphlonemertes (pallida) sp. 20 cf. erneba & Leasi et al. (2016) \\
\hline KT722724 & Ototyphlonemertes erneba & Ototyphlonemertes (pallida) sp. 20 cf. erneba & Leasi et al. (2016) \\
\hline KT722723 & Ototyphlonemertes erneba & Ototyphlonemertes (pallida) sp. 20 cf. erneba & Leasi et al. (2016) \\
\hline KT722722 & Ototyphlonemertes erneba & Ototyphlonemertes (pallida) sp. 20 cf. erneba & Leasi et al. (2016) \\
\hline KM083876 & Ototyphlonemertes erneba & Ototyphlonemertes (pallida) sp. 20 cf. erneba & Leasi and Norenburg (2014) \\
\hline KM083871 & Ototyphlonemertes erneba & Ototyphlonemertes (pallida) sp. 20 cf. erneba & Leasi and Norenburg (2014) \\
\hline KM083866 & Ototyphlonemertes erneba & Ototyphlonemertes (pallida) sp. 20 cf. erneba & Leasi and Norenburg (2014) \\
\hline KM083861 & Ototyphlonemertes erneba & Ototyphlonemertes (pallida) sp. 20 cf. erneba & Leasi and Norenburg (2014) \\
\hline KM083848 & Ototyphlonemertes erneba & Ototyphlonemertes (pallida) sp. 20 cf. erneba & Leasi and Norenburg (2014) \\
\hline KM083869 & Ototyphlonemertes erneba & Ototyphlonemertes (pallida) sp. 21 cf. erneba & Leasi and Norenburg (2014) \\
\hline KT722713 & Ototyphlonemertes erneba & Ototyphlonemertes (pallida) sp. 22 cf. erneba & Leasi et al. (2016) \\
\hline KT722712 & Ototyphlonemertes erneba & Ototyphlonemertes (pallida) sp. 22 cf. erneba & Leasi et al. (2016) \\
\hline KT722711 & Ototyphlonemertes erneba & Ototyphlonemertes (pallida) sp. 22 cf. erneba & Leasi et al. (2016) \\
\hline KT722710 & Ototyphlonemertes erneba & Ototyphlonemertes (pallida) sp. 22 cf. erneba & Leasi et al. (2016) \\
\hline KT722709 & Ototyphlonemertes erneba & Ototyphlonemertes (pallida) sp. 22 cf. erneba & Leasi et al. (2016) \\
\hline KT722708 & Ototyphlonemertes erneba & Ototyphlonemertes (pallida) sp. 22 cf. erneba & Leasi et al. (2016) \\
\hline KT722707 & Ototyphlonemertes erneba & Ototyphlonemertes (pallida) sp. 22 cf. erneba & Leasi et al. (2016) \\
\hline KT730618 & Ototyphlonemertes santacruzensis & Ototyphlonemertes (pallida) sp. 3 cf. santacruzensis & Leasi et al. (2016) \\
\hline KT730617 & Ototyphlonemertes santacruzensis & Ototyphlonemertes (pallida) sp. 3 cf. santacruzensis & Leasi et al. (2016) \\
\hline KT730616 & Ototyphlonemertes santacruzensis & Ototyphlonemertes (pallida) sp. 3 cf. santacruzensis & Leasi et al. (2016) \\
\hline KT730615 & Ototyphlonemertes santacruzensis & Ototyphlonemertes (pallida) sp. 3 cf. santacruzensis & Leasi et al. (2016) \\
\hline KT730614 & Ototyphlonemertes santacruzensis & Ototyphlonemertes (pallida) sp. 3 cf. santacruzensis & Leasi et al. (2016) \\
\hline KT730613 & Ototyphlonemertes santacruzensis & Ototyphlonemertes (pallida) sp. 3 cf. santacruzensis & Leasi et al. (2016) \\
\hline KT730612 & Ototyphlonemertes santacruzensis & Ototyphlonemertes (pallida) sp. 3 cf. santacruzensis & Leasi et al. (2016) \\
\hline KT730611 & Ototyphlonemertes santacruzensis & Ototyphlonemertes (pallida) sp. 3 cf. santacruzensis & Leasi et al. (2016) \\
\hline KT730610 & Ototyphlonemertes santacruzensis & Ototyphlonemertes (pallida) sp. 3 cf. santacruzensis & Leasi et al. (2016) \\
\hline KT730609 & Ototyphlonemertes santacruzensis & Ototyphlonemertes (pallida) sp. 3 cf. santacruzensis & Leasi et al. (2016) \\
\hline KT730608 & Ototyphlonemertes santacruzensis & Ototyphlonemertes (pallida) sp. 3 cf. santacruzensis & Leasi et al. (2016) \\
\hline KM083887 & Ototyphlonemertes santacruzensis & Ototyphlonemertes (pallida) sp. 3 cf. santacruzensis & Leasi and Norenburg (2014) \\
\hline KM083880 & Ototyphlonemertes santacruzensis & Ototyphlonemertes (pallida) sp. 3 cf. santacruzensis & Leasi and Norenburg (2014) \\
\hline KM083865 & Ototyphlonemertes santacruzensis & Ototyphlonemertes (pallida) sp. 3 cf. santacruzensis & Leasi and Norenburg (2014) \\
\hline KM083843 & Ototyphlonemertes santacruzensis & Ototyphlonemertes (pallida) sp. 3 cf. santacruzensis & Leasi and Norenburg (2014) \\
\hline KM083839 & Ototyphlonemertes santacruzensis & Ototyphlonemertes (pallida) sp. 3 cf. santacruzensis & Leasi and Norenburg (2014) \\
\hline KM083830 & Ototyphlonemertes santacruzensis & Ototyphlonemertes (pallida) sp. 3 cf. santacruzensis & Leasi and Norenburg (2014) \\
\hline KM083825 & Ototyphlonemertes santacruzensis & Ototyphlonemertes (pallida) sp. 3 cf. santacruzensis & Leasi and Norenburg (2014) \\
\hline KT730607 & Ototyphlonemertes santacruzensis & Ototyphlonemertes (pallida) sp. 6 cf. santacruzensis & Leasi et al. (2016) \\
\hline KT730606 & Ototyphlonemertes santacruzensis & Ototyphlonemertes (pallida) sp. 6 cf. santacruzensis & Leasi et al. (2016) \\
\hline KT730605 & Ototyphlonemertes santacruzensis & Ototyphlonemertes (pallida) sp. 6 cf. santacruzensis & Leasi et al. (2016) \\
\hline KT730604 & Ototyphlonemertes santacruzensis & Ototyphlonemertes (pallida) sp. 6 cf. santacruzensis & Leasi et al. (2016) \\
\hline KT730603 & Ototyphlonemertes santacruzensis & Ototyphlonemertes (pallida) sp. 6 cf. santacruzensis & Leasi et al. (2016) \\
\hline KT730602 & Ototyphlonemertes santacruzensis & Ototyphlonemertes (pallida) sp. 6 cf. santacruzensis & Leasi et al. (2016) \\
\hline KT730601 & Ototyphlonemertes santacruzensis & Ototyphlonemertes (pallida) sp. 6 cf. santacruzensis & Leasi et al. (2016) \\
\hline KT730623 & Ototyphlonemertes santacruzensis & Ototyphlonemertes (pallida) sp. 7 cf. santacruzensis & Leasi et al. (2016) \\
\hline KM083858 & Ototyphlonemertes erneba & Ototyphlonemertes (pallida) sp. 8 cf. erneba & Leasi and Norenburg (2014) \\
\hline KT730598 & Ototyphlonemertes santacruzensis & Ototyphlonemertes (pallida) sp. 9 cf. erneba & Leasi et al. (2016) \\
\hline KT730597 & Ototyphlonemertes santacruzensis & Ototyphlonemertes (pallida) sp. 9 cf. erneba & Leasi et al. (2016) \\
\hline KT730596 & Ototyphlonemertes santacruzensis & Ototyphlonemertes (pallida) sp. 9 cf. erneba & Leasi et al. (2016) \\
\hline KM083882 & Ototyphlonemertes erneba & Ototyphlonemertes (pallida) sp. 9 cf. erneba & Leasi and Norenburg (2014) \\
\hline KM083873 & Ototyphlonemertes erneba & Ototyphlonemertes (pallida) sp. 9 cf. erneba & Leasi and Norenburg (2014) \\
\hline KM083844 & Ototyphlonemertes erneba & Ototyphlonemertes (pallida) sp. 9 cf. erneba & Leasi and Norenburg (2014) \\
\hline LC311007 & Ototyphlonemertes lei & Ototyphlonemertes (parmula) lei & present study \\
\hline LC311008 & Ototyphlonemertes nakaoae & Ototyphlonemertes (parmula) nakaoae & present study \\
\hline LC311009 & Ototyphlonemertes nakaoae & Ototyphlonemertes (parmula) nakaoae & present study \\
\hline
\end{tabular}


Appendix Continued

\begin{tabular}{|c|c|c|c|}
\hline $\begin{array}{l}\text { Accession } \\
\text { number }\end{array}$ & $\begin{array}{l}\text { Species name registered in } \\
\text { DDBJ/EMBL/GenBank }\end{array}$ & Species name used in this paper & Source \\
\hline LC311010 & Ototyphlonemertes nakaoae & Ototyphlonemertes (parmula) nakaoae & present study \\
\hline LC311011 & Ototyphlonemertes nakaoae & Ototyphlonemertes (parmula) nakaoae & present study \\
\hline LC311012 & Ototyphlonemertes nakaoae & Ototyphlonemertes (parmula) nakaoae & present study \\
\hline LC311013 & Ototyphlonemertes tsukagoshii & Ototyphlonemertes (parmula) tsukagoshii & present study \\
\hline LC311014 & Ototyphlonemertes tsukagoshii & Ototyphlonemertes (parmula) tsukagoshii & present study \\
\hline KT730666 & Ototyphlonemertes fila & Ototyphlonemertes (parmula) sp. 13 & Leasi et al. (2016) \\
\hline KT730665 & Ototyphlonemertes fila & Ototyphlonemertes (parmula) sp. 13 & Leasi et al. (2016) \\
\hline KT730664 & Ototyphlonemertes fila & Ototyphlonemertes (parmula) sp. 13 & Leasi et al. (2016) \\
\hline KT730663 & Ototyphlonemertes fila & Ototyphlonemertes (parmula) sp. 13 & Leasi et al. (2016) \\
\hline KT730662 & Ototyphlonemertes fila & Ototyphlonemertes (parmula) sp. 13 & Leasi et al. (2016) \\
\hline KT730661 & Ototyphlonemertes fila & Ototyphlonemertes (parmula) sp. 13 & Leasi et al. (2016) \\
\hline KT730660 & Ototyphlonemertes fila & Ototyphlonemertes (parmula) sp. 13 & Leasi et al. (2016) \\
\hline KM083867 & Ototyphlonemertes parmula & Ototyphlonemertes (parmula) sp. 13 & Leasi and Norenburg (2014) \\
\hline KM083859 & Ototyphlonemertes parmula & Ototyphlonemertes (parmula) sp. 13 & Leasi and Norenburg (2014) \\
\hline KM083846 & Ototyphlonemertes parmula & Ototyphlonemertes (parmula) sp. 13 & Leasi and Norenburg (2014) \\
\hline KT730659 & Ototyphlonemertes fila & Ototyphlonemertes (parmula) sp. 14 & Leasi et al. (2016) \\
\hline KT730658 & Ototyphlonemertes fila & Ototyphlonemertes (parmula) sp. 14 & Leasi et al. (2016) \\
\hline KT730657 & Ototyphlonemertes fila & Ototyphlonemertes (parmula) sp. 14 & Leasi et al. (2016) \\
\hline KT730656 & Ototyphlonemertes fila & Ototyphlonemertes (parmula) sp. 14 & Leasi et al. (2016) \\
\hline KT730655 & Ototyphlonemertes fila & Ototyphlonemertes (parmula) sp. 14 & Leasi et al. (2016) \\
\hline KT730654 & Ototyphlonemertes fila & Ototyphlonemertes (parmula) sp. 14 & Leasi et al. (2016) \\
\hline KT730653 & Ototyphlonemertes fila & Ototyphlonemertes (parmula) sp. 14 & Leasi et al. (2016) \\
\hline KT730652 & Ototyphlonemertes fila & Ototyphlonemertes (parmula) sp. 14 & Leasi et al. (2016) \\
\hline KT730651 & Ototyphlonemertes fila & Ototyphlonemertes (parmula) sp. 14 & Leasi et al. (2016) \\
\hline KT730650 & Ototyphlonemertes fila & Ototyphlonemertes (parmula) sp. 14 & Leasi et al. (2016) \\
\hline KT730649 & Ototyphlonemertes fila & Ototyphlonemertes (parmula) sp. 14 & Leasi et al. (2016) \\
\hline KT730648 & Ototyphlonemertes fila & Ototyphlonemertes (parmula) sp. 14 & Leasi et al. (2016) \\
\hline KT730647 & Ototyphlonemertes fila & Ototyphlonemertes (parmula) sp. 14 & Leasi et al. (2016) \\
\hline KT730646 & Ototyphlonemertes fila & Ototyphlonemertes (parmula) sp. 14 & Leasi et al. (2016) \\
\hline KT730645 & Ototyphlonemertes fila & Ototyphlonemertes (parmula) sp. 14 & Leasi et al. (2016) \\
\hline KT730644 & Ototyphlonemertes fila & Ototyphlonemertes (parmula) sp. 14 & Leasi et al. (2016) \\
\hline KT730643 & Ototyphlonemertes fila & Ototyphlonemertes (parmula) sp. 14 & Leasi et al. (2016) \\
\hline KT730642 & Ototyphlonemertes fila & Ototyphlonemertes (parmula) sp. 15 & Leasi et al. (2016) \\
\hline KT730641 & Ototyphlonemertes fila & Ototyphlonemertes (parmula) sp. 15 & Leasi et al. (2016) \\
\hline KT730640 & Ototyphlonemertes fila & Ototyphlonemertes (parmula) sp. 15 & Leasi et al. (2016) \\
\hline KT730639 & Ototyphlonemertes fila & Ototyphlonemertes (parmula) sp. 15 & Leasi et al. (2016) \\
\hline KT730638 & Ototyphlonemertes fila & Ototyphlonemertes (parmula) sp. 15 & Leasi et al. (2016) \\
\hline KT730637 & Ototyphlonemertes fila & Ototyphlonemertes (parmula) sp. 15 & Leasi et al. (2016) \\
\hline KT730636 & Ototyphlonemertes fila & Ototyphlonemertes (parmula) sp. 15 & Leasi et al. (2016) \\
\hline KT730635 & Ototyphlonemertes fila & Ototyphlonemertes (parmula) sp. 15 & Leasi et al. (2016) \\
\hline KT730634 & Ototyphlonemertes fila & Ototyphlonemertes (parmula) sp. 15 & Leasi et al. (2016) \\
\hline KT730633 & Ototyphlonemertes fila & Ototyphlonemertes (parmula) sp. 15 & Leasi et al. (2016) \\
\hline KT730632 & Ototyphlonemertes fila & Ototyphlonemertes (parmula) sp. 15 & Leasi et al. (2016) \\
\hline KT730631 & Ototyphlonemertes fila & Ototyphlonemertes (parmula) sp. 15 & Leasi et al. (2016) \\
\hline KT730630 & Ototyphlonemertes fila & Ototyphlonemertes (parmula) sp. 15 & Leasi et al. (2016) \\
\hline KT730629 & Ototyphlonemertes fila & Ototyphlonemertes (parmula) sp. 15 & Leasi et al. (2016) \\
\hline KT730628 & Ototyphlonemertes fila & Ototyphlonemertes (parmula) sp. 15 & Leasi et al. (2016) \\
\hline KT730627 & Ototyphlonemertes fila & Ototyphlonemertes (parmula) sp. 15 & Leasi et al. (2016) \\
\hline KT730626 & Ototyphlonemertes fila & Ototyphlonemertes (parmula) sp. 15 & Leasi et al. (2016) \\
\hline KT730673 & Ototyphlonemertes fila & Ototyphlonemertes (parmula) sp. 16 & Leasi et al. (2016) \\
\hline KT730672 & Ototyphlonemertes fila & Ototyphlonemertes (parmula) sp. 16 & Leasi et al. (2016) \\
\hline KT730671 & Ototyphlonemertes fila & Ototyphlonemertes (parmula) sp. 16 & Leasi et al. (2016) \\
\hline KT730670 & Ototyphlonemertes fila & Ototyphlonemertes (parmula) sp. 16 & Leasi et al. (2016) \\
\hline KT730669 & Ototyphlonemertes fila & Ototyphlonemertes (parmula) sp. 16 & Leasi et al. (2016) \\
\hline KT730668 & Ototyphlonemertes fila & Ototyphlonemertes (parmula) sp. 16 & Leasi et al. (2016) \\
\hline KT730667 & Ototyphlonemertes fila & Ototyphlonemertes (parmula) sp. 16 & Leasi et al. (2016) \\
\hline KT730678 & Ototyphlonemertes fila & Ototyphlonemertes (parmula) sp. 18 & Leasi et al. (2016) \\
\hline KT730677 & Ototyphlonemertes fila & Ototyphlonemertes (parmula) sp. 18 & Leasi et al. (2016) \\
\hline KT730676 & Ototyphlonemertes fila & Ototyphlonemertes (parmula) sp. 18 & Leasi et al. (2016) \\
\hline KT730675 & Ototyphlonemertes fila & Ototyphlonemertes (parmula) sp. 18 & Leasi et al. (2016) \\
\hline KT730674 & Ototyphlonemertes fila & Ototyphlonemertes (parmula) sp. 18 & Leasi et al. (2016) \\
\hline
\end{tabular}

